1992

\title{
Client-Centeredness Multiplied: Individual Autonomy and Collective Mobilization in Public Interest Lawyers' Representation of Groups
}

Stephen Ellmann

New York Law School, stephen.ellmann@nyls.edu

Follow this and additional works at: http://digitalcommons.nyls.edu/fac_articles_chapters

\section{Recommended Citation}

78 Va. L. Rev. 1103 (August 1992)

This Article is brought to you for free and open access by the Faculty Scholarship at DigitalCommons@NYLS. It has been accepted for inclusion in Articles \& Chapters by an authorized administrator of DigitalCommons@NYLS. 


\title{
CLIENT-CENTEREDNESS MULTIPLIED: INDIVIDUAL AUTONOMY AND COLLECTIVE MOBILIZATION IN PUBLIC INTEREST LAWYERS' REPRESENTATION OF GROUPS
}

\author{
Stephen Ellmann*
}

\section{INTRODUCTION}

\begin{abstract}
A major current of contemporary legal scholarship urges us to Arediscover the virtues of groups. The republican citizen finds honor and responsibility through engaging in the public life of her society. ${ }^{1}$ The isolated victim of discrimination and entrenched power finds new hope of resistance in struggling alongside others who share the same experiences. ${ }^{2}$ The partisan puts aside demagoguery in favor
\end{abstract}

* Associate Professor of Law, New York Law School. I am grateful to many people who have made helpful comments about this project, imcluding the participants in Columbia's Clinical Theory Workshop and in the New England clinical teachers' workshop, at both of which I presented an earlier draft of this paper, as well as the faculties of several other law schools at which I discussed these issues. I particularly appreciate the assistance of Robert Amdur, Sue Bryant, Bob Dinerstein, Lucas Guttentag, Heather Hanson, John Leubsdorf, Carol Liebman, James Liebman, Peter Margulies, Thomas Pak, Stephen Pepper, Harriet Rabb, Nancy Rosenbloom, Barbara Schatz, Thomas Shaffer, Jane Spinak, and Judith Whiting. Beth Levine and Susan Widule provided valuable research assistance, and Elizabeth Martim deciphered and transcribed interview tapes. Columbia Law School, where I was teaching during the writing of this Article, gave financial support.

1 Sec, e.g., David Luban, Lawyers and Justice: An Ethical Study 329-37 (1988) (articulating the moral prizes-and prices-of "mutual political commitment"); Michael J. Sandel, Liberalism and the Limits of Justice 179, 183 (1982) (arguing for recognition of the constitutive role of commumity in our very identities, and for an engagement with each other that may enable us to "know a good in common that we cannot know alone"); Frank Michelınan, Law's Republic, 97 Yale L.J. 1493 (1988) (tempering republicanism's potential authoritariarism through a vision of the incorporation of "hitherto excluded" voices in a noncoercive, dialogic process of interaction and influence); James S. Liebman, Desegregating Politics: "All-Out" School Desegregation Explained, 90 Colum. L. Rev. 1463, 1552-65 (1990) (urging recognition of a republican responsibility of every citizen to accord "equal respect" to all other people); Cass R. Sunstein, Beyond the Republican Revival, 97 Yale L.J. 1539 (1988) (articulating an understanding of "liberal republicanisin," in which "political hberty" resides "in collective self-determination" based on attention to diverse perspectives and "publicregarding justifications" for choosing between thein).

2 See, e.g., Stephen Wexler, Practicing Law for Poor People, 79 Yale L.J. 1049, 1053 (1970) (asserting that the appropriate aim of poverty law is "helping poor people to organize themselves" and that traditional practice "hurts poor people by isolating them froin each other"); Lucie E. White, Mobilization on the Margins of the Lawsuit: Making Space for 
of membership im a dialogic community. ${ }^{3}$ The moral reasoner who recognizes the web of connection between herself and others reaches results more humane than those generated from rigidly imdividualistic premises; ${ }^{4}$ so, too, does the person who understands how profoundly she has been shaped as a person by the communities of which she has been a part. ${ }^{5}$ Haunting these visions, however, is a recurrent concern - that the mdividual will be lost within a commumity suddenly all too solidary.

This Article examines the conflicts between the themes of group participation and individual autonomy in the context of public interest lawyers' representation of groups. This is a critical area of legal practice, but one that neither current rules of legal ethics nor current models of lawyer-chent interaction adequately illuminate. Indeed, the reader of the codes of legal ethics might be forgiven for assuming that most legal work is done on behalf of individuals. The Model Code of Professional Responsibility explains the fundainental duty of zealous representation as a consequence of the proposition that "[i]n our government of laws and not of men, each meinber of our society is entitled to have his conduct judged and regulated in accordance with the law ...."6 The Model Rules of Professional Conduct, now a model for the ethical codes of most states, expressly regnlate the conduct of

Clients to Speak, 16 N.Y.U. Rev. L. \& Soc. Change 535, 538 (1987-88) (suggesting that litigation can be an occasion for "participatory, educative [and empowering] experiences for clients and their advocates"); cf. Antliony V. Alfieri, Reconstructive Poverty Law Practice: Learning Lessons of Client Narrative, 100 Yale L.J. 2107, 2143-45 (1991) (naintaining that the image of poor clients as "dependent" can be overcoine through such steps as the organization and involveinent of "client community support groups").

3 See, e.g., Bruce A. Ackerman, Social Justice in the Liberal State (1980) (exploring the justifications for, and the implications of, "neutral dialogue"); Jocl F. Handler, Dependent People, the State, and the Modern/Postmodern Search for the Dialogic Community, 35 UCLA L. Rev. 999, 1001 (1988) (exploring the possibility of dialogic community in relationships that are "at least imitially, characterized by great disparities in power").

4 See, e.g., Carol Gilligan, In a Different Voice: Psychological Theory and Woinen's Development 25-39 (1982); Paul J. Spiegelman, Integrating Doctrine, Theory and Practice im the Law School Curriculum: The Logic of Jake's Ladder in the Context of Amy's Web, $38 \mathrm{~J}$. Legal Educ. 243 (1988).

$s$ See, e.g., Stephen L. Pepper, Autonomy, Community, and Lawyers' Ethics, 19 Cap. U. L. Rev. 939 (1990) (exploring the compatibility of "communitarian morality" and respect for individual autonomy in the context of legal ethics); Thomas L. Shaffer, The Legal Ethics of Radical Individualisin, 65 Tex. L. Rev. 963, 965-66 (1987) (arguing for the critical importance to legal ethics of a recognition that "organic communities ... are prior in life and in culture to individuals").

6 Model Code of Professional Responsibility EC 7-1 (1980) [hereinafter Model Code]. 
lawyers who represent organizational clients-but only in a single rule. ${ }^{7}$

In fact, liowever, a treinendous amount of what lawyers do they do for groups of people. ${ }^{8}$ The vast bulk of corporate representation is in a sense the representation of the many individual owners of the corporation's stock. Uinon representation is, probably a good deal more directly, representation of the union's meinbers. Class action litigation expressly deals witl the interests of groups of individuals who share common concerns but are too nunierous to be individually represented, and the meinbers of inany smaller groups are individually named in the cases that concern thein. There reinam, to be sure, inany cases or inatters in which the only formal client is an individual, but few of these will implicate only that individual's interests. A single child may deinand the desegregation of a scliool systein; one lomeless family's vindication of a right to einergency housing inay lielp otliers win the same benefit in the future; and the gams and losses froin any transaction or litigation are likely to be reaped not only by the "client" but by the client's family.

For lawyers whose work is aimed at achieving social reform on behalf of people who would otherwise lack adequate representationthose lawyers whom I will call "public interest lawyers"'-the role of groups is particularly significant. Faced witl needs far greater than

7 Model Rules of Professional Conduct Rule 1.13 (1983) (as amended through February, 1990) [hereinafter Model Rules]. According to Stephen Gillers and Roy D. Simon, Jr., "approximately 35 states have adopted soine form of the Model Rules." Stephen Gillers \& Roy D. Simon, Jr., Regulation of Lawyers: Statutes and Standards-With Recent Supreine Court Decisions 3 (1991):

8 John Leubsdorf has recently observed that "[i]n reality, legal services today are usually rendered by groups of people for other groups of people, or perhaps by organizations for other organizations." John Leubsdorf, Pluralizing the Client-Lawyer Relationship, 77 Coruell L. Rev. 825, 825 (1992).

9 My definition of "public interest lawyers" resembles that of the Council for Public Interest Law, which defines "pubhic interest law" as "efforts to provide legal representation to previously unrepresented groups and interests. Such efforts," the Council continues, "have been undertaken in recognition that the ordinary marketplace for legal services fails to provide such services to significant segnents of the population and to significant interests. . . includ[ing] the poor, environmentalists, consumers, racial and ethnic minorities, and others." Council for Pub. Interest Law, Balancing the Scales of Justice: Financing Public Interest Law in America 6-7 (1976). Like the Council, see id. at 7, I include in this definition the work of legal services lawyers whose caseloads may consist entirely of individual client-service work. These cases may not seek law reform directly, but I take their underlying rationale to be, at least in part, a redistribution and thus a reform of legal power within society. 
they can hope to meet, ${ }^{10}$ these lawyers must make decisions about what cases and causes to undertake. The problems their clients encounter are not the product of some series of unique imdividual accidents; ratlier, they result at least im part fronı social conditions that affect nany people at once. Meaningful assistance to these clients depends, to sonve extent, on finding legal strategies that target broad situations rather than just individual circumstance, and pubhic interest lawyers can properly inake case selection decisions that take into account whether potential cases will have this broad impact. ${ }^{11}$ The success of these strategies, in turn, may depend on the extent to which they enipower chents outside as well as inside the courts, and so niay hinge on the degree to which they transform this multiphicity of people nito a group.

The upshot is that a great deal of what public interest lawyers do will be done on behalf of groups, either exphicitly or imphicitly. But the various groups of disadvantaged or underrepresented people in our society are not nonolithic. They consist of individuals, whose needs inay im fact be unique and whose relations to the groups to which they inay be said to belong inay range fron hostile to harmonious. ${ }^{12}$ Poor people, like rich people, are formed in and are part of commumities. However, they equally niay seek to change or even to slied soine of the ties that bind then to these communities. Thus there is an inevitable danger that the lawyer who sets out to help disadvantaged people as inembers of groups inay inadvertently succeed in oppressing then (or sone of them) as individuals. So long as we acknowledge and value the capacity of individuals to inake choices that are not entirely dictated by their preexisting group affiliationsin other words, so long as we value individual autononiy-we niust be troubled by the danger to this autonomy inherent in a focus on group interests. My purpose in this Article is to examine the extent of this danger in certain forms of public interest lawyers' representation of chent groups. I will argue that proper representation of groups

10 Luban, supra note 1, at 241-42; see Gary Bellow \& Jeanne Kettleson, From Ethics to Politics: Confronting Scarcity and Fairness in Public Interest Practice, 58 B.U. L. Rev. 337, 342 \& n.26 (1978).

11 So David Luban has argued, and I agree. See Stephen Ellmann, Lawyering for Justice in a Flawed Democracy, 90 Colum. L. Rev. 116, 174 (1990) (reviewing Luban, supra note 1).

12 See William H. Simon, Visions of Practice in Legal Thought, 36 Stan. L. Rev. 469, 47879 (1983-84). 
deinands radical alterations in our usual methods of protecting individual chent autonomy in the lawyer-chent relationship, but that it is possible for lawyers both to limit the intrusions on mdividual autonomy that group interactions generate and to protect a crucial element of individual autonoiny-our choices to make connections-that would be jeopardized by a resistance to group representation.

It might be objected that this imquiry is misdirected from the start, precisely because it rests on an assertion of the miportance of individual autonomy. I do make this assertion, but I do so in a particular way, which needs explanation here. I begin from the proposition that it is impossible for us to know how to weigh the value of individual autonomy against that of group connection. ${ }^{13}$ Thomas Shaffer argues forcefully for the importance of connection on the ground that the crucial determinants of our moral natures are the families and communities into which we are born. ${ }^{14}$ Shaffer takes this account of how we come to personhood as an argument for giving less salience to choice as a moral dimension because, he says, we do not choose these birth commumities. ${ }^{15}$ This sounds reasonable, but actually is unprovable once we step outside the bounds of Shaffer's Judeo-Christian perspective. The Buddhist doctrine of karma (and perhaps other rehgious teachings as well) suggest that we choose, or rather earn, our parents as part of the cycle of birth and rebirth. ${ }^{16}$

Even if we make the conventional Western assumption that we are not responsible for the parental and social forces that shape us as we grow, it does not follow that individual autonomy is unimportant. As Stephen Pepper has thoughtfully suggested in response to Shaffer's argunient, each of us has a history not only of being shaped by groups but of forming new ones and leaving or distancing ourselves froin

13 Thus I agree with Frank Michelman when he says, "I do not know what is good for the soul." Michelman, supra note 1, at 1504 .

14 Thomas L. Shaffer, Legal Ethics After Babel, 19 Cap. U. L. Rev. 989 (1990). Psychological and sociological theories both offer support for Shaffer's description.

is Shaffer maintains that "[w]e are primarily members, not choosers. We are primarily connected, not alone." Id. at 1001-02.

16 Thus Nichiren Daishonin, the Japanese monk revered as the original Buddha by devout members of Nichiren Shoshu (a Buddhist sect now found in many countries around the world), wrote in the thirteenth century to a follower, "It must be ties of karma from the distant past that have destined you to become my disciple at a time like this .... The [Lotus] sutra's statement, 'In hifetime after lifetime they were always born together with their masters in the Buddha lands throughout the universe,' cannot be false in any way." 1 The Major Writings of Nichiren Daishonin 24 (The Gosho Translation Comm. ed.-trans., 1979). 
some of the attachments we formerly accepted or sought out. ${ }^{17}$ This history, moreover, does not begin at soine singular moinent that follows our having been fully shaped by forces beyond our control; we begin shaping, as well as being shaped, early in our hives. Although many of the choices we make may be unwise or immoral, making choices is obviously central to our efforts to create moral value for our hives. ${ }^{18}$

That we are inescapably uncertain about the relative values of autonomy and community counsels against radically devaluing either one-a counsel this Article takes seriously. If lawyer-client relations can be shaped that provide effective representation of chent groups and also secure real protection for the autonomy of those groups' members, these relationships are to be welcomed precisely because they do respect both sets of values. As I will argue, in some contexts such relationships are indeed withm lawyers' reach. ${ }^{19}$

But even if lawyers can simultaneously provide some degree of protection to individual autonomy and the community of a chent group,

17 For Pepper's discussion of our roots in communities and our prerogatives of choice, see Pepper, supra note 5, at 950-57.

18 Luban has recently argued that autonomy has "no intrinsic value." David Luban, Partisanship, Betrayal and Autonomy in the Lawyer-Client Relationship: A Reply to Stephen Ellmann, 90 Colum. L. Rev. 1004, 1037 (1990). As indicated in the text, I view autonomy as an inportant hunian good-but in a sense Luban may not disagree. The argument he develops actually suggests a grcat dcal of what may be called "extrinsic" value for autonomy, which Luban agrees is "closely connected with important values," including moral responsibility, creativity, individuality, and, perhaps most important for present purposes, the principle that one person should not be able to subordinate another. Id. at 1035-43. Though he argues that few lawyers for "paying customers" ever succeed in subordinating their clients to the lawyers' moral views, he observes that "troubling issues of subordination arise" in a nuniber of contexts, many of them falling in the field of public interest law. Id. at 1036-37 \& n.112. Whatever the "intrinsic value" of autonomy, therefore, Luban apparently would recognize its practical significance at least in parts of this domain of practice.

19 In other circunistanees, however, lawyers will not be able to aecommodate so fully the claims of botl autonomy and commumity. The lawyer for a class of thousands or even millions will never be able to have any contact at all with many of the people slre represents, much less to give each of them a meaningful voice in the conduct and outcome of the litigation. Those within the represented class may be quite unaware of what is being done on their belialf, and without power to opt out of the process if they do learn of it. Abram Chayes has commented on the "inevitable incompleteness of the interest representation" in what he calls "public law hitigation," though he by no means endorses indifference to the interests of those affected by such hitigation; on the contrary, he is concerned to encourage more rather than less complete representation of these interests. Abram Chayes, The Role of the Judge in Public Law Litigation, 89 Harv. L. Rev. 1281, 1310-13 (1976). There is good reason to doubt, however, how complete the spectrum of interests represented in such eases has actually been. See 
it might be argued that as an ethical matter, they should not. Honoring both concerns may be good, the argument would go, but decisively favoring one over the other would be better. Perhaps lawyers could provide more effective representation of chent groups if they gave less protection to individual members. Conversely, perhaps they could better protect individual members if they curtailed to some extent the services they provide to groups.

No algorithm exists by which to resolve such conflicts mathematically, and no escape hatch permits us to avoid them. If we have good reason to acknowledge the value of both autonomy and connection im our moral lives, however, then it inakes sense to question a calculus which operates to privilege one set of claims so sharply over the other. Moreover, we have ample grounds for denying that these two values are necessarily opposed. Rather, as I will argue later, people's involvement in groups can both protect and express their autonomy; and at the same time, groups that respect their members' autonomy inay draw strength from that very feature of their make-up. ${ }^{20}$ In the inany cases where considerations of autonomy and community comcide, only a method of representation that lionors both will succeed im honoring either.

The case for the compatibility of autonomy and community in lawyers' representation of chients, like the case for the compatibility of wisdom and freedom in democratic self-government, remains in part an aspiration and even an expermient, rather than a descriptive fact. To the extent that this experiment fails, and autonomy and connection prove incoinpatible, I find the claims for autononiy, for a sphere of freedoin and choice that each of us can enjoy despite others' desires to encroach on it, very powerful. This Article pursues the aspiration of harmonizing these two values, however, by seeking to identify the steps lawyers can take to represent certain chent groups in ways that

generally Deborah L. Rhode, Class Conflicts in Class Actions, 34 Stan. L. Rev. 1183 (1982) (examining a range of problems on this score).

It is no part of my thesis to challenge the propriety of such litigation, even though it drastically curtails the client prerogatives that the rules of professional ethics see as bound up with individual autonomy. In truth, such cases often may not sharply pose the choice between group and individual interests, because such litigation may well be the only way to secure the class members' legal rights. In this context, a process that invades client autonomy by depriving class members of control over their case may be essential to winning for these same clients benefits that they can then use to enhance their autonomy.

20 See infra notes 64-66 and accompanying text. 
will foster both group connection and individual autonoiny. I will begin by looking closely, in Part $I$, at the rules of ethics and of law that govern whether the lawyer's relationship with a set of people will be seen as the representation of inultiple individuals or of a unitary group. As we will find, the relevant rules are surprisingly open, and in fact permit - even compel-lawyers in a wide range of situations to assess whether their chent is, or should be, a group, a set of individuals, or only a single person. Moreover, the choice is a fateful one, for the consequences of adopting one or another of the possible characterizations include sharp variations in the nature of the lawyer's duties of loyalty and confidentiality.

Given the reality of group representation in our law, it becoines all the more important to determine how to make such representation coinpatible with individual autonomy. I will argue in Part II that lawyers who seek to separate individual group meinbers froin their groups in adherence to a model of imdividual representation disserve these mdividuals' choices and status as group inembers, and thereby actually harm individual autonoiny. It follows, then, that lawyers should recognize groups as their chents, and counsel them as such. In doing so, as I will suggest in Part III, lawyers can appropriately find gnidance in the aspirations and the techniques of "client-centered" practice with individuals. Connseling a group, however, is not the same as counseling the imdividual members of the group, separately and in succession, and somehow computing the sum of the individuals' preferences so as to obtam the judgment of the group as a whole. Groups that are making their own decisions do so as groups, through one structure or another that gives voice to the members' mutual interaction, discussion and debate, and lawyers who seek to counsel such groups will need to participate in, or at least affect, the decisionmaking processes that characterize group action.

To say whether such representation can be squared with a continuimg respect for individual autonomy, however, requires an examination of how this engagement with the group's decisionmaking will in fact work. This is an iminense question, and one that has been far froin completely explored. It is the focus of Part IV, in which I will examine the counseling relationship between lawyers and groups, and in particular between lawyers and groups that are small enough so that the lawyer could conceivably speak to all of the inembers, not necessarily one by one, but at least in a community ineeting hall. 
With groups of this size, it is possible for lawyers to take direction from their chents, rather than undertaking the responsibility for choice largely on their own as they might in a vast class action. Taking direction from one's clients is, of course, the ideal of client-centered practice. As we explore the nature of "group chentcenteredness," however, we will see that the careful elucidation of an individual client's thoughts, concerns and choices that characterizes chent-centered practice on a one-to-one basis must be altered quite dramatically if the lawyer is to assist in the process of group decisionmaking.

For lawyers seeking to bring about social reform, moreover, workmg with groups presents an opportunity less evident in individual case work-an opportunity to empower chents by helping them to realize their collective capacity as pohtical actors. Although lawyers may win political victories for their chents in a variety of ways-for example, by lobbying in the legislature or by winning media attention focused on a lawsuit-the path offering perhaps the greatest potential for the enhancement and subjugation of mdividual autonomy is one in which the lawyer seeks to foster a political mobilization of the clients themselves. The idea of the lawyer as mobilizer seems far distant from the careful restraints of chent-centered individual practice, but I will argue in the final Part of this Article that lawyers can still fashion a "group client-centered" role with this political aspiration, a role in which they protect individual autonomy while at the same time rendering real service to collective mobilization.

\section{The Definition of the Client}

\section{A. Four Frameworks for Representation}

Defining the chent is often difficult, even when only one person is being represented. In individual representation, the lawyer's task, and the chent's, is to ensure that the lawyer comes to understand this particular chent as he or she is, and not as the lawyer finds it natural, or convenient, or attractive to imagine the client to be. This is no easy matter, particularly for lawyers who are overburdened by caseload and look to routinized systems of legal triage for relief. ${ }^{21}$ Even law-

21 See Alfieri, supra note 2, at 2110-13, 2123-25; Carl J. Hosticka, We Don't Care About What Happened, We Only Care About What is Going to Happen: Lawyer-Client Negotiations of Reality, 26 Soc. Probs. 599 (1979). 
yers who want to provide individualized service are in danger of misreading their clients, for the ways that clients describe themselves are inevitably influenced by the questions they are asked, and the desires clients articulate are affected by the sense of the possible that lawyers provide. $^{22}$ These effects, moreover, are not merely a inatter of selfpresentation, because chents, like the rest of us, change in response to what they experience, so that what the lawyer says to the chent may affect who a chent is.

Whatever the intricacies of defining the individual chent, matters are vastly more complex when the lawyer is dealing with more than one individual. Consider the following situation:

Eight tenants from a particular apartment building meet with a lawyer at the local legal services office. The tenants explain that they, and the forty other families in the building, have struggled for years to make their landlord provide them with a minimally safe and habitable building. Many of them have, as individuals, protested to the landlord; some have teinporarily withheld their rent; and soine have inoved out when they could. Now, however, these eight men and woinen have decided that conditions in their building are intolerable, and that they want to take action together to seek redress. In the course of the ineeting, it becoines clear to the lawyer that although most of these eight people are quite determined to continue hiving in the building, two or three might be tempted to take a cash settlement that would enable them to find better housing elsewhere-even though their doing so might jeopardize the chance of the other tenants' obtaining needed repairs. The lawyer agrees to help them forinulate and carry out a plan of attack that will put the maximum legal pressure on the landlord to accede to the tenants' deinands.

This lawyer inight characterize her relationship to the tenants in any of four quite different ways. These different characterizations, as we shall see, span a continuum froin an insistence on the status of each individual as a client to a vision of these individuals, and their many other co-tenants, as a class. The consequences of these characterizations, not surprisingly, can powerfully affect the work the lawyer does for the tenants, and the relations the tenants will have with each other. Where individual representation is the inodel, the lawyer must assiduously work for each individual chent, but may well have

\footnotetext{
22 See Gary Bellow \& Bea Moulton, The Lawyering Process: Materials for Clinical
} Instruction in Advocacy 233-34 (1978); Simon, supra note 12, at 476-77. 
to withdraw altogether if the chents develop conflicts of interest. In group representation, on the other hand, the lawyer's fidelity to each individual is considerably curtailed, but her ability to help the individuals to achieve their collective ends is enhanced. These points will become inore clear as we examine each of the four possible characterizations.

\section{Individual Representation, Multiplied}

First, a lawyer might see herself as representing eight separate individuals. This, of course, would be ethically unproblematic if the eight had identical interests, but they do not. Instead, after the first ineeting it is already apparent that the tenants may eventually have quite different preferences as to the remedies they seek, and that these different preferences might result in sharp disagreements within the group. Under the Model Rules, however, "a possible conflict" does not necessarily bar the lawyer from representing all eight. ${ }^{23}$ If the lawyer reasonably beheves, in light of her experience with such cases, that the tenants will ultimately agree on the issue of relief, or that each will be able to get his or her preferred relief without undercutting the others' positions vis-à-vis the landlord-and if the chents consent to her representing them all despite the possibility of future conflict-then she is free to do so. ${ }^{24}$ Each tenant will then be her chent, and she will owe a duty of loyalty and confidentiality to each one as an individual..$^{25}$ If a true conflict of interest does emerge, then she may well have to withdraw from the representation of all eight, whatever the difficulties they may face im finding alternative counsel. ${ }^{26}$

23 Model Rules, supra note 7, Rule $1.7 \mathrm{cmt}$.

24 Id. Rule 1.7. The lawyer might also be able to minimize the risk of a fatal conflict of interest by "limit[ing] the objectives of the representation," id. Rule 1.2(c), provided each client consents. The narrower the scope of the representation, the more likely it will be that disagreements among the clients will not create a conflict of interest bearing on the particular objectives for whicls this lawyer is responsible.

${ }^{25}$ See generally Charles W. Wolfram, Modern Legal Ethics $\$ 7.1 .3$ (Student ed. 1986) (discussing the loyalty and confidentiality principles that underlie the conflict rules).

26 Under the Model Rules a lawyer is barred from representing anyone wlose interests are "materially adverse" to those of any client she had previously represented in "the same or a substantially related matter," absent the former client's consent. Model Rules, supra note 7, Rule 1.9(a). Though the Model Code, supra note 6, contains no specific prohibition to the same effect, a similar result lias "not uncommon[ly]" been reacled under it. Wolfram, supra note $25, \S 7.4$, at $363-64$. 


\section{Intermediation}

Not every disagreement ripens into a conflict of interest, however, and if disagreement among the tenants on the issue of rehef does develop, the lawyer can contimue to represent all eight if she can characterize her relationship to the tenants im a second way-as a mediator or, in the language of the Model Rules, an "intermediary."27 Under this rubric, the lawyer is free to help the chents to reach a coinpromise that is in their collective best interest, rather than vigorously defendimg each imdividual's preexisting preferences. However, the lawyer can play the role of intermediary ouly in rather narrow circumstances. Each chent must consent, after consultation, to the lawyer's playing of this part-and if any of the chents revoke their consent she must withdraw. ${ }^{28}$ In addition, she herself must

reasonably believe[] that the matter can be resolved on terms compatible with the chents' best interests, that each chent will be able to make adequately informed decisions in the matter and that there is little risk of material prejudice to the interests of any of the clients if the contemplated resolution is unsuccessful . . . .29

These conditions are not easily met. ${ }^{30}$ The lawyer is obliged to protect each chent's confidentiality and to keep each chent adequately informed, and these duties can be directly at odds: ${ }^{31}$ the more any chent insists on confidentiality, the harder it will be for the lawyer to

27 Model Rules, supra note 7, Rule 2.2. Mediation is also recognized as a lawyering role by the Model Code, supra note 6, EC 5-20, although it is not the specific focus of any of the Code's Disciplinary Rules.

28 Model Rules, supra note 7, Rule 2.2(a)(1), (c); see also infra note 33.

29 Id. Rule 2.2(a)(2).

30 Geoffrey C. Hazard, Jr. and W. William Hodes comment that the intermediation rules "sound so many warnings and urge so much caution as to reveal a distinctly grudging attitude towards mediation as such. The rules are so confining that prudent lawyers often will not undertake this role, but will treat the representation as one involving a 'consented conflict' under Rule 1.7(b) imstead." 1 Geoffrey C. Hazard, Jr. \& W. William Hodes, The Law of Lawyering: A Handbook on The Model Rules of Professional Conduct $§ 2.2: 103$ (2d ed. 1990). That lawyers prefer to act under Model Rule 1.7(b) is ironic, for although this Rule's provisions for dealing with "consented conflicts" are much more laconic than Rule 2.2's, the more elaborately stated safeguards of Rule 2.2 might all be seen as implicit in Rule 1.7(b) as well.

31 See Model Rules, supra note 7, Rule $2.2 \mathrm{cmt}$. (identifying these duties). Presumably she has these duties because here, as in "consented conflict" cases, she is understood to be representing multiple individual clients, to each of whom she owes full loyalty and confidentiahity. 
keep her other chents adequately informed. ${ }^{32}$ And because a failure of the mediation will likely preclude her from representing any of the chents $^{33}$ and probably subject all of what any one of them has said to her to discovery by the others, ${ }^{34}$ she can hardly believe that there is little risk of material prejudice unless she can say that the matter not only can but probably will be resolved on terms compatible witli the clients' best interests. ${ }^{35}$

\section{Organizational Representation}

Given the vigilance on behalf of individual clients reflected in these first two formulations of the lawyer's role, it is startling - even stunning - to encounter the radically different regime envisaged by Model Rule 1.13. The first subsection of this rule declares that "[a] lawyer employed or retained by an organization represents the organization acting througl its duly authorized constituents."36 This simple sentence adopts the "entity theory" of organizational representation, under which the lawyer for the organization does not represent its sliareholders, or officers, or employees, but instead represents an artificial entity, the organization. ${ }^{37}$ No doubt the most frequent application of this proposition is in the field of corporate representation, but

32 Perhaps there is sometimes room for the lawyer to keep one chient's secrets because the other clients do not need to learn them-but exercising this discretion will surely require "a delicate balance." Id.

33 Id. Rule 2.2(c). The Rule does not by its terms permit the lawyer to continue representing any of the people for whom she served as an intermediary, even with the others' consent-though perhaps the possibility of consent should be inferred.

34 This grim prospect is the result of "the prevailing rule . . . that as between commouly represented chents the [attorney-client] privilege does not attach." Id. Rule $2.2 \mathrm{cmt}$. This position holds even though the lawyer representing multiple clients lias an ethical duty to proteet each chient's confidentiality. See supra note 31 and accompanying text. The Comment to the Model Rules' provision on confidentiality explains that

[t]lie attorney-client privilege applies in judicial and other proceedings in which a lawyer may be called as a witness or otherwise required to produce evidence concerning a client. The [ethics] rule of chent-lawyer confidentiality apphes in situations other than those where evidence is sought from the lawyer through compulsion of law.

Model Rules, supra note 7, Rule $1.6 \mathrm{cmt}$.

${ }^{35}$ Hazard and Hodes observe that "[t]he clues that should lead a lawyer to refuse to undertake a common representation are those suggesting a likelihood of failure." Hazard \& Hodes, supra note 30, § 2.2:203.

${ }^{36}$ Model Rules, supra note 7, Rule 1.13(a). See also Model Code, supra note 6, EC 5-18 ("A lawyer employed or retained by a corporation or similar entity owes his allegiance to the entity and not to ... [any individual] person connected with the entity.").

37 Hazard \& Hodes, supra note $30, \S 1.13: 201$. 
it may apply in a variety of other contexts, including our housing lawyer's relationship to this group of tenants.

Its bearing on this situation stems from the fact that Rule 1.13 applies to umincorporated associations as well as to organizations having corporate form. ${ }^{38}$ Neither the Rule itself nor the accompanying Comment defines "organization," but two influential commentators have urged a very expansive treatinent of the term in this context. Geoffrey C. Hazard, Jr. and W. Willianı Hodes suggest that the rule would also apply to seventeen homeowners who "form a group that hires lawyer L to prosecute a nuisance action" and agree that they will all abide by any settlement that twelve of their number approve. ${ }^{39}$ These facts, Hazard and Hodes indicate, give this set of people "an identity apart from the individuals who comprise it,"40 and thus transform them into an organization.

On this logic, the eight tenants, too, can readily be seen as such an organization. It is true that these tenants have not, so far as the stated facts reveal, agreed aniong themselves on any such decisionmaking process. Perhaps they need not do so; perhaps they becoine an organization if they sinply think of themselves as a group. But if they do need to adopt some structure, then their lawyer can help them do so. After all, lawyers lielp clients establisli organizations all the time. The lawyer could suggest that the tenants agree on a procedure for resolving disagreements among themselves, and if, after proper counseling about the potential consequences, they did reach an appropriate

38 Somewhat imprecisely, the Comment exphicating Model Rule 1.13 states that "[t]he duties defined in this Comment apply equally to unincorporated associations." Model Rules, supra note 7, Rule $1.13 \mathrm{cmt}$. Presumably this observation is meant to refer to the duties defined in the Rule itself, duties that are discussed in the Comment.

39 Hazard \& Hodes, supra note $30, \S 1.13: 203$. The authors note that "some courts would treat the situation as one in which seventeen individuals have hired the same lawyer, each retaining all the rights of a client," but they urge that the organizational characterization is "[t]he better view." Id.

40 Id. $\$ 1.13: 103$. The authors comment there that

[t] me more formal the association, the longer its duration, and the more elaborate its purposes, the inore likely it is that the group will be regarded as an entity that is distinct from its individual constituents. But even a small group informally organized for a limited purpose can be considered an entity. Indeed, a group can be formed primarily Id. for the very purpose of retaining counsel. 
agreement, the lawyer could represent them as an organization rather than as eight separate clients. ${ }^{41}$

The consequences of this recharacterization are striking. Because the lawyer now represents the entity, she no longer owes unqualified loyalty or confidentiality to any of the eight tenants as individuals. ${ }^{42}$ Hence if one tenant provides her with information, she need not convey this information to each of the others uuless doing so is required by her duty of loyalty to the organization. ${ }^{43}$ Conversely, if providing the information to the group is necessary im order to keep it adequately informed, the lawyer has no duty to protect the imdividual tenant's secrets. ${ }^{44}$ So, too, if the eight constituents of the organization develop disagreements, her obligation is not to remani neutral as between them. Rather, her obligation is to provide the best counsel slie can to the organization (though adopting a neutral stance might still be appropriate, if neutrality best served the organization).

Even if the tenants' disagreements ripen into actual conflicts of mterest, their lawyer will not automatically have to withdraw, for she does not represent the tenants as individuals. Her chent is the group itself, and the fact that some constituents of the group now dissent from its collective decision does not automatically bar her from contimumg to do the bidding of the group as an entity. ${ }^{45}$ So, for exaniple, if the tenants liave agreed to abide by any settlement that two-thirds of them approve, the lawyer can settle the case on behalf of the group despite the wishes of the minority. The shift from the norms of imdi-

41 The fact that there are only eight tenants, rather than the seventeen homeowners in Hazard and Hodes' example, should not be a bar to "entity" status. Many organizationspartnerships, in particular-can consist of only two people. ABA Comm. on Ethics and Professional Responsibility, Formal Op. 361 (1991) specifically confirms that partnerships are "organizations" under Rnle 1.13. The Opinion notes, however, that "[i]n sinall partnerships, as with closely held corporations, it is more difficult to distmguish between representation of the entity and of its individual owners." Id. at n.5.

42 Hazard \& Hodes, supra note 30, § 1.13:106.

43 Id. $\$ 1.13: 107$. If the information is relevant to the group's affairs, and if all members are entitled under the group's rules to participate equally in the group's decisions, then in all likelihood loyalty would require disclosure of this information to each of the tenants. Cf. ABA Comm. on Ethics and Professional Responsibility, Formal Op. 361 (1991) (stating that " 'information relatiug to the representation' of the partnership ... normally may not be withheld [by the partnership's lawyer] from the individual partners").

44 Hazard \& Hodes, supra note 30, § 1.13:107.

45 Hazard and Hodes emphasize that "[i]f need be, ... [the lawyer] can even litigate on behalf of the entity against its former constituents, because they do not qualify as former clients for purposes of [Model] Rule 1.9." Id. § 1.13:106. 
vidual representation is particularly vivid here, for if the eight tenants constituted eight individual chents, each of them might have an unwaivable right to approve or reject any settlement. ${ }^{46}$ In short, the modest steps by which a set of people can transform theinselves into a group sharply alter the role the lawyer can play, and in ways that facilitate group action at the expense of imdividual prerogatives.

\section{Class Representation}

The fourth characterization of the lawyer's relationship to this set of eight people is scarcely inentioned in either the Model Code or the Model Rules. ${ }^{47}$ This characterization treats the eight individuals as the named representatives of a class of all the tenants in the building (a group of perhaps 150 people or more). ${ }^{48}$ The lawyer cannot turn the tenants into class representatives without their consent, ${ }^{49}$ but once this consent has been granted the lawyer acquires a freedoin from the wishes of the individual chients that im some ways exceeds even that conferred by Model Rule 1.13.

Indeed, whereas Rule 1.13 facilitates a group's collective action, the class action device is primarily concerned only with the group's collective representation. The result of class action status may well be to empower groups of people by facilitating their access to court, but the people so empowered are not empowered as agamst their lawyer. Certainly this is true as to the named class representatives, for accord-

46 See id. $\S 1.13: 203$. Rule 1.2(a) specifies that "[a] lawyer shall abide by a chent's decision whether to accept an offer of settlement of a matter." Model Rules, supra note 7, Rule 1.2(a). This protection is not removed by Rule 1.2(c)'s authorization for lawyers to "limit the objectives of the representation if the client consents after consultation." Id. Rule 1.2(c). Instead, the Comment declares that "the client may not be asked ... to surrender . . . the right to settle hitigation that the lawyer might wish to continue." Model Rules, supra note 7, Rule $1.2 \mathrm{cmt}$; accord Model Code, supra note 6, EC 7-7.

47 For modest exceptions to this generalization, see Model Rules, supra note 7, Rule 7.2 cmt.; Model Code, supra note 6, DR 2-104(A)(5). Charles Wolfram observes that "[d]espite the prommence of ... . [conflict] issues in class actions, nothing in the professional codes addresses them directly. Instead, the matter has been left, correctly, to regulation through the close judicial supervision that ideally attends class actions." Wolfram, supra note $25, \S 8.14$, at 493. Whether this silence of the codes is altogether "correct" is debatable.

48 See Fed. R. Civ. P. 23.

49 Lawrence M. Grosberg, Class Actions and Client-Centered Decisionmaking, 40 Syracuse L. Rev. 709, 754 \& n.204 (1989). Potential class representatives must consent to their status because of the various effects that having their issue handled as a class action may have on them-not least, that they lose the power to determine when and on what terms the matter will be settled. See infra notes $50-55$ and accompanying text. 
ing to the standard interpretation of Rule 23 of the Federal Rules of Civil Procedure, the lawyer owes her inost fundamental duty of loyalty not to them but to the class itself. ${ }^{50}$ With judicial approval, ${ }^{51}$ she may settle the case despite the objections of a majority of the named representatives. ${ }^{52}$ Moreover, the existence of disagreements within the class by no means automatically precludes class certification, ${ }^{53}$ although if these disagreeinents are profound enough they may lead to the designation of subclasses with separate representation. ${ }^{54}$ Finally, even - or especially-the class as a whole lacks the power to direct the lawyer's actions, because the class typically has no decisionmaking structure through which it can act. As a result, the lawyer's responsibility for gauging what is in the class's best interests is profound, and a court inay approve a settlement endorsed by the class lawyer even if most class meinbers-and, it would seein, most named class representatives-object. ${ }^{5 s}$

50 Parker v. Anderson, 667 F.2d 1204, 1211 (5th Cir. 1982) ("The compelling obligation of class counsel in class action litigation is to the group which makes up the class."); Rhode, supra note 19, at 1203 ("counsel's fiduciary obligations run to the class as a whole").

51 See Fed. R. Civ. P. 23(e). Rule 23(e) does not by its terms require judicial approval for a lawyer's refusal to settle a case, but authority to scrutimize such decisions might be miplied there or perhaps more readily in Rule 23(d), which empowers trial courts to make "appropriate orders" in "the conduct of actions." Fed. R. Civ. P. 23(d). Among these can be orders "requiring, for the protection of the members of the class . .., that notice be given ... to some or all of the members of any step in the action." Id. The Manual for Complex Litigation, Second states that if "[c]lass representatives ... favor acceptance of a settlement offer that class counsel believe is madequate... class counsel should ordinarily ask the court to determine whetler preliminary approval should be given and a fairness hearing scheduled." Manual for Complex Litigation, Second, § 30.43, at 240 (1986) [hereinafter Manual]. The Manual also observes, however, that "the court should rarely approve a settlement that counsel do not recommend." Id.

52 County of Suffolk v. Long Island Ligliting Co., 907 F.2d 1295, 1325 (2d Cir. 1990) (affirming a class action settlement despite claims that it was opposed by a majority of the class representatives). The Manual for Complex Litigation, Second, lowever, instructs that "[t]le views of the class representatives are ... often entitled to special weight because they have a better understanding of the case tlian most members of the class. Moreover, their objections to a settlement may be symptomatic of strained attorney-client relations that may have affected settlement negotiations." Manual, supra note 51, § 30.43, at 240.

53 See 7A Charles A. Wright, Arthur R. Miller \& Mary K. Kane, Federal Practice and Procedure § 1768, at 330-31 (2d ed. 1986); Rhode, supra note 19, at 1194-95 (describing conflicting case law on whether "substantial internal opposition" will, or will not, "preclude class status").

54 See Fed. R. Civ. P. 23(c)(4)(B). For a discussion and critique of subclassing and similar responses to disunity in class actions, sec Rhode, supra note 19, at 1221-32.

55 See TBK Partners v. Western Union Corp., 675 F.2d 456, 462 (2d Cir. 1982) (opposition of majority of the class "cannot serve as an automatic bar to a settlement"). 


\section{B. The Lawyer's Role in Selecting a Framework}

It may be surprising to learn how far existing ethical and legal principles perinit lawyers to depart from the stringent safeguards of individual client autonomy that play so important a part in the profession's norms. But because this discretion does exist, lawyers must decide how to use it. It might be objected that this potential departure from the protection of individual autonomy is unproblematic, because it is the clients themselves who decide whether to be characterized as individuals, an orgamzation, or representatives of a class. In that sense, orgamzational or class representation can be seen as resting on a valid waiver of some amount of individual autonomy. But as a practical and a legal matter, this choice of characterization does not rest exclusively with the chents. One source of the lawyer's influence on this decision is that it is plainly her responsibility to counsel these individuals on their cloice. ${ }^{56}$ Perhaps the eight tenants who arrived in the lawyer's office did not conceive of theinselves as an "organization" or as the representatives of a class; it is up to the lawyer to explain the significance of these characterizations and to counsel these individuals on what characterization they and the lawyer should adopt. ${ }^{57}$ In addition, the lawyer may well have the authority to condition her representation of the chents on their agreeinent to one status or another. ${ }^{58}$ Although ch-

56 Both the Model Rules and the Model Code call on lawyers to counsel their chients. See Model Rules, supra note 7, Rules 1.4, 2.1; Model Code, supra note 6, EC 7-8. Counseling at least entails a clear identification of the likely consequences of cacli option available to the client, and most lawyers probably agree that good counseling also often requires the lawyer to state her opinion of what the client should do in light of these consequences. Cf. infra notes 79-80 and accompanying text (discussing the role of advice-giving im a model of client-centered lawyering).

57 Perliaps, on the other liand, the tenants have already decided to constitute themselves as a group, but the lawyer foresees sharp conflicts among the group ineinbers and fears that the result will be that individuals within the group will be severely liarmed. Here, lier obligation would be to counsel the eight as a group-for that is low the tenants currently see themselves-about the possible wisdom of disbanding, or of being represented as individuals. Slie might also seek private meetings with the individual members to pursue these matters; going outside the group meeting could be an impingement on the tenants' decision to present themselves as a group, but might be justified here on paternalistic grounds. For furtlier discussion of the considerations affecting the lawyer's use of private ineetings with individual group members, see infra notes 68-73, 96-101 and accompanying text.

58 See Model Rules, supra note 7, Rule 1.2(c). The Comment to this provision states that "[t]lie terms upon which representation is undertaken may exclude specific objectives or means. Such limitations may exclude objectives or means that the lawyer regards as repugnant 
ents may object to these conditions, chents who have few options for obtaining counsel are not in a good position to insist on their objections, because the lawyer is likely to have the authority to decline to represent them if she considers the form of representation they seek to be repugnant or imprudent. ${ }^{59}$ Having rejected these chents, she may then solicit others, through advertisimg, ${ }^{60}$ personal letters, ${ }^{61}$ or evenif the lawyer is a public interest lawyer-through im-person contacts. ${ }^{62}$

Indeed, the lawyer's discretion to enter into individual or group representation would have come into play even if only a smgle tenant had originally consulted her. Had she learned that her first chent was one of many facing similar problems, she might have concluded that collective efforts were needed. ${ }^{63}$ At that poimt, she might have assisted this tenant to begin organizing a tenants' group. Alternatively, she might have developed a court case naming this individual as a representative of a class, or she might even have declined to rep-

or imprudent." Id. at cmt. The Model Code contains no such broad and express authorization of limitations on goals or means. See, e.g., Model Code, supra note 6, DR 7101(B)(1) (authorizing the lawyer to waive a right of her chent "[w]here permissible"). Charles Wolfram, while tracing the ambiguities im the Model Code, suggests that it "essentially takes the position [about the allocation of power between lawyer and chent] that the 1983 Model Rules restate." Wolfram, supra note $25, \S 4.3$, at 157 .

59 Under the Model Rules, lawyers can withdraw from cases on the basis of such judgments, and presumably can declime to undertake the cases in the first place as well. See Model Rules, supra note 7, Rule 1.16(b)(3). See also id. Rule 1.2(c) (authorizing agreements to limit the objectives of representation). The provisions of the Model Code appear to confine lawyers' right to withdraw more tightly, see Model Code, supra note 6, DR 2-11O(C)(1)(e), and perhaps the right to refuse cases is also slightly more constrained under the Code than under the Model Rules. The Code's EC 2-26 might be read to confirm the existence of such a constraint in its call for lawyers to accept their share of "unattractive" litigation. Id. EC 2-26. But this call is not dramatically different from language to be found in the Model Rules, see Model Rules, supra note 7, Rule $6.2 \mathrm{cmt}$., and EC 2-26 goes on to declare that "[a] lawyer is under no obhigation to act as advisor or advocate for every person who may wish to become his chient ..." Model Code, supra note 6, EC 2-26.

60 Bates v. State Bar of Arizona, 433 U.S. 350 (1976).

61 Shapero v. Kentucky Bar Ass'n, 486 U.S. 466 (1988).

62 Compare In re Primus, 436 U.S. 412 (1978) (finding solicitation on behalf of ACLU protected by the First Amendment as exercise of "associational freedom") with Ohralik v. Ohio State Bar Ass'n, 436 U.S. 447 (1978) (holding that the Ohio Bar Association could constitutionally discipline an attorney for soliciting clients for pecumary gain).

63 The potential value of collective response is one of the recurrent concerns in the "rebellious idea of lawyering against subordination" being articulated by Gerald López. See Gerald P. López, Reconceiving Civil Rights Practice: Seven Weeks in the Life of a Rebellious Collaboration, 77 Geo. L.J. 1603, 1608, 1706, 1714-15 (1989). See also sources cited supra note 2 (endorsing the inobilization of disadvantaged groups). 
resent this tenant, if the tenant was uninterested in collective action, and launched her own effort to find a group to represent.

Because lawyers can wield so profound an influence on the characterization of their chents, they inust be sensitive to the values at stake in its exercise. The rules of ethics suggest that the bond between an individual chent and his lawyer, a bond in which the chent's secrets are jealously guarded and his interests zealously advocated, is an essential protection of individual autonomy. Principles of chent-centered practice suggest that even within this attorney-chent dyad, the chent's autonoiny is still in danger from lawyers who wittingly or unwittingly override the client's own wishes in favor of outcoines that the lawyers prefer. Group representation cannot protect individual autonomy in the same ways, or perhaps to the same extent, as individual representation does. As Part II of this Article will show, however, group representation is by no means always opposed to individual autonomy; instead, group representation is essential to protect those aspects of autonoiny that people express through their membership in groups-as well as those values beyond autonomy's purview that republicans, feminists and others suggest collective engagement inay serve. This is not to deny, though, that individual and group interests inay diverge, even in the context of a group that does in a broad sense give expression both to autonomy and connection. Parts III and IV will respond to this reality by outlining the elements of a "group client-centeredness" by which lawyers can give substantial protection to these cross-cutting concerns.

\section{INDIVIDUAL AUTONOMY AND GROUP REPRESENTATION}

It might be teinpting to respond to the threat to autonoiny seemingly posed in group representation by saymg that such representation should no longer be permitted. If there were a fundamental contradiction between group representation and mdividual autonomy, this response would be a powerful one. But this argument cannot succeed, despite the force of its fundamental premise that individual autonomy must be protected, because it ignores the value that group action and association inay have for individuals, and the degree to which effective groups inay draw strength precisely from their respect for individual members' autonoiny.

The assertion that people can protect their imdividual wishes through group meinbership is hardly a revelation; a central lesson of 
modern life is that it is very difficult for people to protect themselves against others' encroachment except through group involvement that overcomes the barriers to effective individual action. This lesson has not been lost on those who jom together as corporate shareholders, or as union meinbers, and William Simon is certainly right to say that other people, too, can benefit from group action and representation. ${ }^{64}$ But group membership can honor mdividual autonomy in a more direct, less instrumental, sense as well.

People's membership in groups is often itself an expression of their individual autonomy. People choose to become husbands or wives, they choose to join tenants' associations, and they choose to give their time to the ACLU or the NAACP or any of a countless range of other groups. To some degree every such commitment limits the chooser's future choices, but our acceptance of these limits is precisely an expression of our autonomous capacity to shape our hives. Most such choices also reflect a willingness to accept some future collective judgments with which the individual member disagrees; generally, it is no part of these decisions to insist that everything must go our way or the deal is off. Even our membership in groups that we did not originally choose to join, such as (we may assunie) the families, rehigions, and races into which we are born, may express our autonomy, for our continued acknowledgement and celebration of these originally imvoluntary ties will over time come to contam at least an eleinent of choice. ${ }^{65}$ Indeed, this blending of the voluntary and the involuntary is a recurrent feature of our hives. For example, the eight tenants of our exainple have becoune victims of their landlord without having aspired to that status. Their need to defend themselves agamst the landlord is unchosen, perhaps bitterly regretted; their decisions about how, if at all, to meet that need nonetheless will involve countless choices, exercises of autonomy, in shaping their own lives. When we make connections, or adhere to them, we express our autonomy.

At the same time, groups can draw strength from their endorsement or accommodation of their members' autonomy. It will not do to exaggerate the extent to which groups undermine themselves when they deny their members' right to participate in or secede from the group's decisionmaking-cultish rehgions and disciplimed armies

64 See Simon, supra note 12 , at $481-82$ \& n.35.

65 See supra notes 14-18 and accompanying text. 
attest to the power of nondemocratic groups to inspire and mobilize their members. But groups that encourage their members to speak their minds, and to listen to other members as they do the same, reduce the risks of fanaticism, corruption, and disruptive secessionall risks that are far from fanciful-and can foster in their stead mutual recognition, understanding, and growth. ${ }^{66}$ When people sincerely jom groups committed to such internal practices, they make, and benefit from, a pledge to protect each other's autonomy.

In short, for the law generally to undercut or deny our group connections would, even judged solely from the perspective of autonomy, be bizarre. It would deny us the efficacy that group action can provide. It would also deny us the autonomy expressed im our choices to jom or adhere to groups. By devaluing commitments that lielp define who we are, moreover, it would amount to a form of disrespect for our capacity to shape our own hives. If it is possible to honor these aspects of autonomy without sacrificing other, even more pressing, autonomy claims - as I will argue in Part IV-then this disrespect cannot be justified in the name of autonomy. On the contrary, I suggest it amounts to a moral wrong. ${ }^{67}$

It might be argued, however, that lawyers' insistence on representing each member of a group as an individual in no way demes the

66 See Michelman, supra note 1, at 1526-28 (offering a republican response to the reality of social dissensus, an inage of "a self whose identity and freedom consist, in part, in . . . test[ing] its current understandings ... communicatively, by rcaching for the perspectives of other and different persons"); Sunstein, supra note 1, at 1548-51, 1554-55 (describing republican aspiration to the achievement of "general agreement through dehberation" aided by empathy). See also Martha Minow, The Supreme Court, 1986 Term, Foreword: Justice Engendered, 101 Harv. L. Rev. 10, 70-95 (1987) (arguing that justice requires us to "acknowledge and struggle against [our] partiality by making an effort to understand [others'] reality," while recognizing the tragic necessity of sometimes choosing between conflicting values).

67 Cliarles Fried describes "disrespect between persons" as "a form of immorality" in his well-known and controversial article, Charles Fried, The Lawyer as Friend: The Moral Foundations of the Lawyer-Client Relation, 85 Yale L.J. 1060, 1088 (1976). I take it that he holds this view beeause he sees disrespect of another person as a denial of that person's status as "a responsible, valuable, and valuing agent." Id. at 1069. Fried's conception of human agents places an intense value on autonomy, a value so great that he suggests that "[p]erhaps we recognize family ties because, after all, there often has been an element of clioice, but also because - by solne kind of atavism or superstition-we identify with those who share a part of our biological natures." Id. at 1071. This view seems to miss the real inportance of apparently unchosen affiliations in our moral lives, see Shaffer, supra note 5, but if autonomous clioice deserves any recognition as a fundamental part of our lives tlien unnecessarily denying us the prerogative of choice does seen morally wrong. 
group members' affiliation to their group. But this is not always true. Consider an example: ${ }^{.6}$

A husband and wife come to a lawyer to have their wills prepared. The husband explains the terms that they want in their wills; the lawyer asks the wife if she agrees with what her husband has said, and she nods and says "yes," but nothing else. The lawyer prepares the documents accordingly. But when the couple return for their next meeting, at which the wills are to be signed, the lawyer explains that he first wants to talk with the wife alone. Outside the husband's presence, the lawyer asks the wife if the will as drafted is actually in accordance with her wishes.

I suggest that the lawyer's decision to speak with the wife outside the husband's presence may well constitute a refusal to accept the mtegrity of the couple's mutual affiliation. This choice perhaps reflects the lawyer's feeling that the husband might be overriding the wife's preferences, that the lawyer can only get at the truth by freeing the wife temporarily from her husband's domination, and that it is the lawyer's place to judge the quality of this couple's jomt decisionmaking. ${ }^{69}$ But people who choose to marry have committed themselves to a vast range of joint decisionmaking, the fairness of which will be essentially unreviewable by any third party. Such commitments can fade, but perhaps this one has not. If these spouses remain committed to inaking choices together, that does not mean that when they arrive in the lawyer's office, they miphedly represent that they are im perfect agreement or that their jomt decisions are made in perfect ways. On this reading of the story, however, they may miphedly represent that they are committed to joint decisionmaking, one product of which they now wish the lawyer to implement. In the face of that commitment, the lawyer's insistence on separating the spouses is a form of disrespect for this couple as a couple-and they may feel it as such.

But this story can be read very differently. Perhaps this couple's affiliation was already disturbed, as the wife's virtual silence might

68 This example is drawn, and modified, from a problem originally posed in the Legal Ethics Forum section of the American Bar Association Journal. The Case of the Unwanted Will, 65 A.B.A. J. 484 (1979). For a thoughtful discussion of this "case," see Shaffer, supra note 5, at 968-72.

69 The lawyer may hold these attitudes, or he may not. The lawyer might insist on a separate interview with the quieter party simply as a prophylactic and routine safeguard rather than because of any such assessment of this marriage, and the husband and wife might understand the lawyer's action in just this way as well. 
have loudly declared..$^{70}$ Certainly there is reason to be anxious about men's power withm marriages (and in other relationships with women), and to be sensitive to the potentially grim meanings of this woman's silence-although it remains possible that she made an entirely uncoerced choice to be relatively quiet. ${ }^{71}$ Such considerations surely did give this lawyer reason for concern, and I do not suggest that his obhigations to this couple as a group called on him to dismiss these concerns from his mind.

Even so, his decision to separate the two spouses remains problematic. Unless some legal or moral mandate justified removing this decision from the purview of the couple, ${ }^{72}$ the lawyer had other options available that conld have tested the validity of the alternative readimgs of the wife's near-silence without so disrupting the couple's association. These options are techniques of working with these two spouses together-techmiques that are meant to vindicate, where possible, both the group's collective association and its members' individual autonomy. Delineatimg such techniques, and exploring both their

70 In the original version of this story, the wife says nothing at all in the joint session, and when questioned alone she reveals that she would not sign the will as drafted if her husband "were not to know the ultimate disposition of her estate." The Case of the Unwanted Will, supra note 68 , at 484 .

71 Perhaps she handled the family's taxes, whereas her husband was responsible for estate planning. Perhaps she found making a will unnerving, although her husband was undisturbed by it. Perhaps she and her husband had talked at length about the general shape the wills should take, and spelling out the details to the lawyer struck her as routine or even boring.

72 Perhaps wills should be considered specially individual matters, so mdividual that each testator must be given a special opportunity to shed the bonds of whatever groups he or she is a part of. So, too, coinpetent adults might have a special right to make their own health care decisions, a right whose protection requires that a physician spend soine time alone with a patient facing a major medical choice.

Similarly, criminal defendants inight well be seen as having an unwaivable right to decide how to handle their cases, no matter how intense the contrary wishes of any group of which they were a part. (If so, criminal lawyers might still be able to condition their representation of potential clients on the clients" "committing [themselves] to the decisions of the group," in the words of a retainer form quoted in Creative Defenses in Civil Disobedience Cases, 42 Nat'1 Law. Guild Prac. 97, 117-18 (1985), but clients on this view would at least have to be told that they could always change their minds about this commitment.) Lawyers might also have a corollary duty to interview the individual members of a set of criminal defendants separately to ascertain their willingness to act in a fashion that allowed the lawyer to provide multiple representation without conflict of interest-even if the meinbers made clear that they regarded such separate interviews as an affront to their mutual affiliations. Because at least soine special solicitude for individual autonomy seems appropriate in criminal representation, this Article's recommendations for lawyering on behalf of groups are focused on civil rather than criminal representation. 
value and their limitations, will be the focus of Part IV of this Article; here, my purpose is only to illustrate that such methods of accommodatimg group and individual claims are possible. Indeed, they are readily apparent; after all, another explanation of the wife's failure to speak at length is that the lawyer has not asked her questions that called on her to do so. Such questions could well be asked, but in the presence of the husband; indeed, the lawyer could tell both spouses together that it was important for each of them to explain to him their reasons for wanting these wills. The lawyer could even have told them that sometimes people do not see issues that they should consider until they talk things through with a third party, and thus urged them to speak not for his benefit but for each other's. ${ }^{73}$

All of these steps respond to the possibility that the wife needs the lawyer's help to express herself in the face of her husband's dommation, yet they do so without parting the spouses and in fact they call on the spouses themselves to resolve their own possible problem. Once these steps have been taken, others of course inay turn out to be appropriate, in light of the ways that husband and wife respond to these efforts by the lawyer. The lawyer may decide that separating the spouses is what is called for; he inight even see the need for inore fundainental interventions, such as advising separate representation or recommending a family therapist. Or he might conclude that this inan and woman have freely and collaboratively thought through the issues involved in inaking wills, and ask thein to execute the documents then and there.

As this example suggests, automatic disaffiliation is not a satisfying response to the tension between individual autonomy and group membership. Though this example also suggests some better responses, it remains to be seen whether individual autonomy can in general be ineaningfully protected within the context of group representation. That is not a question of theory so much as of techrnque; to answer it, we inust identify actual inethods of lawyering through which attorneys can honor both autonomy and connection.

73 All of the techniques mentioned in the text are verbal. Nonverbal techniques can also be useful, as demonstrated in Robert M. Bastress \& Joseph D. Harbaugh, Interviewing, Counseling and Negotiating: Skills for Effective Representation 137-40, 157 (1990) (analyzing body language in a lawyer's interview of a married couple with a potential tort clain). 


\section{The Standard of Group Client-Centeredness}

Before we begin to examine techniques of group counseling, we need a standard for comparison-that is, we need a model of lawyers' practice witlı individual clients $\mathrm{m}$ which we are satisfied that individual autonomy is being protected, so that we can coinpare what lawyers can do in group representation witl what they do in this form of individual practice. In fact, however, designing a method of interviewing and counseling individual clients that will infallibly ascertain their true wishes is beyond our grasp, and probably always will be. The interactions between lawyer and client in some measure shape both parties, and when the less powerful meinber of this dyad is the client it seeins likely that the client will be more shaped than sliaping.

Nonetlieless it is helpful to begin witl the inodel of "client-centered lawyering" as a benchmark from individual practice, for despite its imperfections this model does aspire to, and should in good part realize, the goal of protecting the autonomy of mdividual clients. ${ }^{74} \mathrm{Cli}$ ent-centered practice rests on the premise that individuals should make their legal decisions for themselves. But they should not inake these decisions on impulse or in ignorance. Instead, it is the lawyer's job to win the client's trust and cooperation, so that the lawyer can understand the client's situation and engage the client in a very careful process of decisionmaking. Winning the chent's trust is by no means automatic, and the lawyer inay liave to nurture the client's cooperation in a variety of ways. Perliaps most important, the lawyer must offer the client her einpathetic understanding-she must convey to the client that she hears, understands, accepts and does not judge liim. ${ }^{75}$ In this way, the lawyer forges a "commumity of two" in which

\footnotetext{
74 A number of scholars have formulated guidelines for legal practice reflecting a "clientcentered" conviction that lawyers should interact attentively and helpfully, rather than domineeringly, with chients. See Bastress \& Harbaugh, supra note 73; Thomas L. Shaffer \& James R. Elkins, Legal Interviewing and Counseling in a Nutshell (2d ed. 1987). I rely here, however, on the model of client-centeredness provided in David A. Binder, Paul Bergman \& Susan C. Price, Lawyers as Counselors: A Client-Centered Approach (1991) [hereinafter Lawyers as Counselors]. In an earher article, I discussed ways that client-centered practice (as exphicated in David A. Binder \& Susan C. Price, Legal Interviewing and Counseling: A ClientCentered Approach (1977) [hereinafter Legal Interviewing and Counseling]) falls short of complete fidelity to individual clients' autonony. See Stephen Ellınann, Lawyers and Clients, 34 UCLA L. Rev. 717, 733-53 (1987).

75 See Lawyers as Counselors, supra note 74 , at 40-44, 46-68.
} 
effective counseling can occur. ${ }^{76}$ Then, with the lawyer's guidance, the chent will go through a series of decisionmaking steps, first articulating his objectives, then identifying the alternatives open to him, next reviewing the pluses and minuses of each one. The lawyer participates in each of these stages with the client, helping the chient to identify his various concerns and to collect them together for his ultimate choice, ${ }^{77}$ and perhaps bolstering his behef that he can indeed handle his situation and the task of inaking decisions about it. ${ }^{78}$ In the process, the lawyer will certainly offer the chent advice about the likely consequences of the various alternatives. ${ }^{79}$ If the chent so requests, the lawyer inay also offer explicit advice about what option the chent should choose; this advice should nornally be based on her understanding of the values the chient adheres to, as the lawyer has ascertained thein in the course of the counseling process. In addition, the lawyer has the prerogative of offering unsolicited advice, whetlier to correct misjudgments she beheves tlie client is inaking or to express her own moral concerns about the client's plans. ${ }^{80}$

The lesson of chent-centered practice seems to be that the protection of individual autonomy requires an intimate and detailed engagement between the lawyer and the chent. This is a disturbing lesson to take to an assessinent of group practice, because it is inconceivable that such an engagement could take place between the lawyer and

76 William Simon applied the term "community-of-two" to what he called the "Psychological Vision" of lawyer-chent relations in William H. Simon, Honı Psychologicus: Notes on a New Legal Formalisn, 32 Stan. L. Rev. 487, 492 (1980) (quoting Philip Rieff, The Triumph of the Therapeutic: Uses of Faith After Freud 52 (1960).

77 See Lawyers as Counselors, supra note 74, at 287-308. The authors are careful to point out that the actual process of counseling is not rigidly sequenced, but rather is "typically cyclical." Id. at 310.

78 Binder, Bergman, and Price by no means suggest that lawyers offer lavish praise of their clients' decisionmaking abilities-perhaps because sucl praise would be botl condescending and ineffective. The sheer process of carrying out the steps of the counseling process in accordance with the lawyer's guidance, however, should often lielp clients to feel in command of their situation. At least indirectly, moreover, what the chent-centered lawyer says should encourage this feeling. Thus Binder, Bergman, and Price offer an example of a preparatory explanation preceding the counseling process, an explanation in which the lawyer sketches the steps of the process and then observes, "This will give you a solid basis for whatever decision you ultimately make." Id. at 289.

79 Id. at 260, 293-95.

80 Id. at 279-86, 347-61. Binder, Berguran, and Price sanction considerably more advicegiving by lawyers than did Binder and Price in the predecessor volume. See id. at xxii. For a critique of the position taken on this issue in Legal Interviewing and Counseling, supra note 74 , see Ellmann, supra note 74 , at $744-48$. 
each member of a group in a meeting between the lawyer and the group. Group members are generally unlikely to reveal themselves to their fellow members with the candor that they might be brought to show with the lawyer alone. Even if the members of a group were each prepared for such public revelations, none of them-nor the lawyer-would have time for the process. And even if everyone had courage and time enough for such a venture, at the end of it there would still have to be a decision by the group. Successfully making that collective judgment, a process often fraught with the potential for disagreement and disunity, will require forms of interaction that the encounter of a single lawyer and chent does not encompass.

It is no solution to these probleins to suggest that the lawyer should do client-centered counseling with each inember of the group, separately, and then represent the group based on the suin of the imdividuals' individually-stated preferences. Such a program would be dooined to failure, for three distinct reasons. First, as soon as the group attained even modest size an effort to interview and counsel each of its members would be impossibly expensive in terms of the lawyer's time and (for whoever was paying for that time) in terms of inoney as well. Second, even if the lawyer could hold such sessions with each member, her effort to calculate the "sum" of the individuals' preferences would at best be imprecise, for no mathematical calculus allows the easy combination of a host of preferences, with all the differences of perception and imtensity that may underhe them. ${ }^{81}$

Third, even if both of the preceding problems could be remedied, the lawyer would have to recognize that the sum of the members' preferences as voiced to her is not the equivalent of the group's decision. Group members influence each other, whether the group is a married couple or a larger assembly. People who choose to become members of groups have chosen to enter a setting im which they will influence and be influenced, and in which decisions they make as a group will be the product of this interaction. To take the sum of the members' preferences without the tempering effects of this interaction is to eliminate the very process that the members themselves have evidently accepted as the path for refining their individual assessments

81 See Richard H. Pildes \& Elizabeth S. Anderson, Slinging Arrows at Democracy: Social Choice Theory, Value Pluralism, and Democratic Politics, 90 Colum. L. Rev. 2121, 2134 (1990) ("[N]o noncontroversial, objective way to gauge such [preference] intensities has been found."). 
and combining them into a collective judgment. It is also to substitute for the group members' mutual impact the lawyer's substantial influence, whether intentional or unintentional, exerted on each group member in the privacy of a one-on-one encounter. The only way the lawyer can obtain a collective decision is to engage, in some way, with the group's collective processes. ${ }^{82}$

Let us consider, therefore, the contours of client-centered counselimg when the client is a group. ${ }^{83}$ In domg so, we will primarily be

82 Where the number of chents is very large, as in some class actions, it is likely to be impossible for the lawyer to meet with, or elicit any colleetive deeision from, the group as a whole. See supra note 19. (Such groups, for that very reason, are not the focus of this Article, see supra pp. 1110-11.) With groups of this size, the lawyer may resort to meeting separately with a few individual members, who will serve as (hopefully) representative examples from whom the lawyer can discern the sentiments of the many absent members. Larry Grosberg advocates this sort of sampling of class member sentiments in Grosberg, supra nóte 49, at 76869,778 . Opimion polling may also be useful as another source of a "snapshot" of chent thinking. See id. at 778; Rhode, supra note 19, at 1256.

If these individual chents express differing views, however, then the lawyer must decide how to harmonize their diverse sentiments. Here, as in the representation of smaller groups, it may be helpful for the lawyer to ask the several class members to meet together, and hammer out their own compromise position. This process would make sense if the class members would indeed see themselves as "in the same boat," and would acknowledge a responsibility to each other that could best be elucidated in shared discussion rather than in separate contacts with the lawyer alone; $I$ think it is reasonable to assume that class members would hold these views, although this assumption should certainly be open to rebuttal. Even if this assumption is correct, in any event, where the participants in this meeting are only a small fraction of the actual class, the lawyer cannot hope for certainty that their preferred solution is the preferred solution of the class, and she is likely to have to make judgments of her own about what to seek on behalf of her chients. For an insightful exploration of ways the lawyer might make these judgments, see Nancy Morawetz, Bargaining, Class Representation, and Fairness (paper presented at Columbia Clinical Theory Workshop, Nov. 22, 1991) (on file with The Virginia Law Review Association).

Although this Article is concerned with describing how lawyers should interact with group clients when such interaction actually is feasible, the problem of absent members is not wholly eliminated by this focus. Surely it is quite common that many members of groups who theoretically could assemble for a meeting with their lawyer will in fact fail to do so. (For a discussion of the difficulties of eliciting high participation in group meetings with lawyers, see Rhode, supra note 19, at 1234.) The importance of the lawyer's learning the opinions of absent members, or gauging how they would react to the views of the members who do attend, will depend on the degree to which the people who come to the meetings are representative of the others, either because they are typical of their fellows or because they have been empowered by the others to represent them.

83 The analysis that follows assumes that the lawyer is actually able to deal directly with the group. This assumption will not always hold true, for some groups will have leaders or agents (house counsel, for example) who speak to the lawyer, and who-perhaps accurately, perhaps not-represent that they speak for the group. Groups of disadvantaged people have the saine prerogative to dcal with their lawyer through designated agents as do the members of a 
explicating the kind of lawyer-client relations that should be permitted in the group representation sanctioned by Model Rule 1.13, althougli some of whit I propose sliould be useful even when the lawyer's relationship to the people slie represents is characterized as the representation of multiple individuals or of a class-indeed, wlienever the lawyer represents, and meets jointly witli, more than one person in the same inatter. ${ }^{84}$ Broadly, we may say that just as standard clientcenteredness seeks to encourage individual chents to make decisions througli a careful, deliberate and rational process, so group clientcenteredness would seek the same achievement from the group. Broadly, too, the elements of a well-considered decision are the same for a group as for an individual. Multiple decisionmakers, like individuals, should clarify their goals, identify the available courses of action, weigh their pluses and mimuses, and then decide what to do. As we will see, however, the details of group decisionmaking are quite different from the process of individual choice. Specifying the elements of group client-centeredness is partly a question of identifying techniques thiat are responsive to these realities of group functionimg. The clioice of techniques, lowever, is not just a question of efficiency but also of morality. The tecliniques to be adopted sliould be those that will advance the autonomy and functionimg of the group, so as to reap the benefits of group association and action, but tliese techniques

corporate board of directors. Hazard and Hodes observe, indeed, that "[t]he lawyer can best serve the [entity] client by keeping lines of communication open to those whose job it is to act for the entity, and being guided by their judgments, which she should normally assume are in the best interests of the entity." Hazard \& Hodes, supra note 30, § 1.13:109, at 400 .

Nonetheless, the lawyer for an organizational client must also be aware of the possibility of the agents' unfaithfulness to the entity for which they act, and may have to take action when she encounters it. See Model Rules, supra note 7, Rule 1.13(b), (c). The gravity of this risk may be greater, moreover, in soine groups than in others, and the need for vigilance by the lawyer correspondingly greater as well. See infra note 86 . In many relatively loosely organized groups, im addition, it may not be entirely clear to the lawyer whose job it actually is "to act for the entity," and Hazard and Hodes consider it the lawyer's first responsibility to ascertain this. Hazard \& Hodes, supra note $30, \S 1.13: 109$, at 400 . It inay therefore be necessary for the lawyer to initiate contact with the group's otlier meinbers for this reason.

Perhaps more important, many nembers of the groups that public interest lawyers represent may be quite inexperieneed in handling the organizational and substantive issues that their organizations confront. They seem likely to welcome the lawyer's direct interaction, and likely to profit from it as well.

84 Thus, for example, the lawyer representing a group whose meinbership has delegated responsibility for decisions bearing on the lawyer's work to a board may never neet with the group as a whole, but she inight well make use of tliese techniques if she niet witl the board. 
should also protect the autonorny of the individual inembers, whose decisions to enter or reinain in groups are an essential part of what makes groups worth protecting and representing. ${ }^{85}$ The guidelines in the following Sections seek to respond to the issues of both technique and morality.

Before we begin, however, it is important to bring to the surface an important premise einbedded to some extent in both the einpirical description I have just given of how groups make decisions and in the nonnative prescription I have just made for the fashioning of techniques that protect both autonomy and comrection. This premise is that groups do in fact decide through a process of shared decisioninaking by the ineinbers. This premise inay seen self-evident, but in fact it is not even always true. Sornetimes people voluntarily join, and feel deeply loyal to, groups in which they know that their views will not be taken into account on many or inost questions; those who join armies, or soine churches, are exainples. I do not question people's right to join such groups, or (in general) the right of their leaders to exercise the power over group ineinbers that such groups generate.

In developing the contours of group chent-centeredness, however, I will be describing ways of lawyering that are inost appropriate for groups that accept dernocratic values, and accept in particular that the ineinbers theinselves are the ultimate decisioninaking authority and that significant decisions should norinally reflect the inembers' input. Groups founded on these principles may be the most promising structure, at least in many parts of our hives, for honoring both individual autonorny and mutual comrection. In addition, groups accepting these premises are a characteristic forn of private association in this country. I suspect, inoreover, that most groups of disadvantaged people represented by public interest lawyers actually would affirm these values. Techniques suited for the representation of such groups, accordingly, should be valuable in a broad array of cases.

How fully any given group adheres to these values is, to be sure, an einpirical question. It is a question to which some groups will have generated clear answers long before the lawyer's arrival on the scene. Where such answers exist, the lawyer should norinally abide by thein (and if need be, modify her techniques accordingly), on the ground

85 This standard reflects the argument made earlier that both the claims of connection and of autonomy deserve to be honored. See supra notes 13-20 and 64-67 and accompanying text. 
that they represent this set of people's collective judgment about the balance they will keep between the claims of autonomy and group connection. The lawyer's deference to such group rules should not be absolute, however, for she cannot ignore-though she should not exaggerate-the possibility that even affiliations that people have in some sense, or at some time, chosen are now profoundly oppressive. ${ }^{86}$

Particularly in the groups that public imterest lawyers are likely to represent, however, it seems hikely that often this question will not have been clearly or conclusively answered in advance. Where the answer is not fixed, moreover, the lawyer herself may affect it, by sponsoring one form of group process or another. ${ }^{87}$ In such circumstances, the moral desirability of democratic processes, and the wide popular acceptance of democratic noruns in this country, counsel in favor of a presumption that the group is committed to such principles. Let us now turn, therefore, to the elements of representing democratic groups.

86 For an instance of such possible oppression, see the discussion of the married couple making a will, supra notes 68-73 and accompanying text. Plainly groups differ in the degree to which they constitute a threat to their members' autonomy. Family membership, for example, is hardly a voluntary choice for young children, yet we would not normally imagine that a family in which parents could "outvote" their small children was an oppressive institution. Similarly, corporations may offer hittle effective voice to those who dissent froin management's practices, yet our concern for minority shareholders is somewhat diminished by our awareness of how easily they often can "exit" the corporation by selling their shares. For an insightful contrast between the characteristics of "meinbership" in corporations and unions-the latter arguably presenting much more reason for concern about internal democracy-see James G. Pope, Two Faces, Two Ethics: Labor Union Lawyers and the Emerging Doctrine of Entity Ethics, 68 Or. L. Rev. 1, 20-22, 27-28 (1989). So, too, considerable attention to the protection of the individual members of such groups as tenant associations may be appropriate, in part because the members may lack the knowledge, self-confidence, and resources needed to mount independent challenges against their leaders.

87 The lawyer should, I suggest, be particularly protective of the autonomy of individual members when the lawyer herself brought their group into existence. Her influence on the members' constituting themselves as a group may have been altogether berign, and their acceptance of her advice altogether free. But the danger that a skilled and sympathetic professional may even inadvertently push people into associations they would not otherwise have accepted puts the lawyer who gave such advice under a duty to monitor its results. This responsibility would not be one of indefinite duration, because surely at some point the lawyer could fairly say that the group had acquired its own momentum. On the other hand, the more the lawyer was involved in continued nurturance of the group's existence, the more this speeial duty to the members could persist as well. 


\section{The Techniques of Group Client-Centeredness}

\section{A. Winning Members' Trust by Forging Lawyer-Client "Communities"}

A basic lesson of client-centered practice is that clients do not automatically trust their lawyers, or communicate frankly and fully with tlrem. Such trust and cooperation must be won, because there are strong reasons for clients not to speak frankly to their lawyers. Clients n1ay fear that revealing the trutli will hurt their cases. Perhaps more important, clients are people, and so they are interested in obtaining their lawyers' approval; the niore the facts or concerus of the client's situation cast him in what he perceives as a bad light, the less willing he will be to reveal then fully. ${ }^{88}$ In individual client-centered practice, a central tool for overcoming these obstacles is the very carefully nurtured attorney-client "community of two." Like lawyers for individual chents, lawyers representing groups should certainly try to win the group niembers' trust-but they will not be able to niake such free use of the "community of two."

Lawyers for individual clients address their chents' mistrust in a nuniber of ways. Such a lawyer promises her client confidentiality, a promise that professional codes suggest is crucial to lawyer-chent communication, presumably because it will be taken to mitigate the danger that the lawyer will use what slie learns in a way that damages the chent. ${ }^{89}$ She speaks to this same danger further by assuring her client of her desire to help (and tlien proceeding to act helpfully). ${ }^{90}$ At the same time, she takes account of her chent's entotional needs by listening attentively, and by responding to what slie hears with einpathy or nonjudgmental acceptance. ${ }^{91}$ She also applauds her chent's efforts to provide information. ${ }^{92}$ Slie niay even, however unintentionally, give lier client the sense that she actually approves of and concurs in the chent's feehings and views. ${ }^{93}$ Wielding these techniques

88 See generally Lawyers as Counselors, supra note 74 , at $35-40$ (identifying seven "inhibitors" to open client cominunication).

${ }^{89}$ See Model Rules, supra note 7, Rule $1.6 \mathrm{cmt}$.; Model Code, supra note 6, EC 4-1.

90 Lawyers as Counselors, supra note 74, at 22 ("repeatedly convey[ing] a desire to help" is an attribute of chent-centered practice).

91 Id. at $40-42,52-61$.

92 Id. at 43.

93 See Ellmann, supra note 74 , at 737-39. 
and assurances, the lawyer seeks to build a community of two ni which the client feels safe, nurtured and vindicated.

Like lawyers representing individuals, tlie lawyer who represents groups nuust also nurture her clients' trust. Tlie lawyer for a group can promise the nienibers confidentiality-as a group. Slie can also affirm lier desire to lielp, applaud the group's working together, listen attentively, and respond einpathetically. But her use of these techniques is subject to important constraints. So long as slie ineets witl the group inenibers only as a group, the lawyer cannot forge exclusive communities of two, because the other nemibers of the group form a constant and potentially competitive audience for her encounter with any one of tlieir number. The lawyer who responds to a chent's expression of strong feelings by saying enipliatically "I certainly understand low upset you feel" risks saying to the listening group that she considers the contrary position of other members provocative and even wrong. ${ }^{94}$ As a result, slie inay often liave to temper the empatlietic responses tliat would be appropriate in individual representation. The impact of this restraint on the individual to whom the lawyer responds would be less potentially significant if the members of the group were theniselves conveying to each otlier the degree of unhesitating support and acceptance tliat tlie lawyer can give to a single client. Sonie group members, even some entire groups, may behave this way-but surely most do not. Tlie result can easily be that even as the lawyer attempts to convey a measure of empathetic regard for a group member wlio lias voiced an unpopular opimion, otluer members are offering mucli more confrontational responses.

The lawyer for a group niay also face anotlier barrier to her formation of communities of two-namely, tlie prior existence of another community, with its own members and norms: tlie client group itself. This community inay be long established and firmly organized. Even if its members are quite diffuse, lowever, and liave actually been brought together by the lawyer, a set of people who are capable of coming togetlier for sonie shared purpose are likely to find they liave much in common already - and are likely to create more. Moreover, as mucli as tlie lawyer may want to serve this group, she will often not be seen autoniatically as "one of us," for slie may not share a culture,

94 Barbara Schatz alerted me to the risk of inadvertent alliance through empathy in group situations. 
a class, a gender, or a race with the bulk of the group's members.95 Members of the group may be far from eager to put their faith in her.

By contrast, the lawyer for an individual-even an individual with whom the lawyer shares little by way of background-is much better situated to generate this influential community of two. It is true, of course, that each mdividual client is probably a member of a variety of groups and communities outside the lawyer's office, and that many chients may not readily trust a lawyer whom they consider an outsider. But even these chents may be deeply dependent on their lawyers for advice, and may well be guided by norms of deference to the powerful and prestigious, norms that counterbalance or outweigh their feelings of suspicion. Perhaps most important, the lawyer dealmg with an individual chent typically deals with him alone, and faces no direct challenge to her efforts to mold their relationship. The lawyer who attends a meetimg of her chent group is never more than one of the contending (or cooperating) personalities on the scene.

The lawyer might respond to such barriers by meeting with individual group members outside the confines of group meetings. Doing so, however, may be taken by some members as a sign that the lawyer is trying to manipulate them and to undercut what they have done as a group. ${ }^{96}$ Even in this settimg, in any case, she cannot establisl exclusive communities of two. Legally, she owes a duty of loyalty to the entity or to the other members (depending on the definition of the chent), which constrains lier ability to promise confidentiality to the mdividual with whom she speaks. Psychologically, she is constantly in danger - in this individual's eyes, and in the eyes of the others - of

95 Or she may not share a pohitical viewpoint. I have had the experience of acting on behalf of a group of student radicals, with whose goals I sympathized but in whose methods I had not joined. I and the other law school professors with whom I worked on this case must have seemed painfully legalistic and conservative to many of these students, and we struggled to get thein to consider our advice.

96 The example of the estate lawyer's insistence on ineeting separately with the wife before coinpleting work on a married couple's wills illustrates this risk. See supra notes 68-73 and accoinpanying text. This is not to say, however, that meeting separately with individual group inembers is always as probleinatic as I suggested it would have been in this example. Most groups' members are not as tightly bound to each other as married couples are; in addition, most meetings with individual group members need not entail the blunt separation of the meinbers at the lawyer's direction that the wills case featured, but instead can be more gently integrated into a larger, ongoing process of interaction between the lawyer and the group. Indeed, in such a sustained interaction it would be natural, perhaps inevitable, for the lawyer soinetimes to be in touch with individual members rather than with the group as a whole. 
entering unwittingly into an alliance with the individual with whom she speaks or of seemmg to want to do so. ${ }^{97}$ Unless she wants such an alliance, she needs to be particularly careful not to imply that she does. This may make it essential to hold comparable meetings with the other members, and to make sure that everyone knows of the lawyer's impartial distribution of her time. ${ }^{98}$ It may also make it essential to tone down the degree of empathy that the lawyer offers to any one group member, even outside the presence of the others, so as to limit the danger that the recipient of the lawyer's empathy will report it to his fellow members as alliance.

Even if the lawyer who rehes on such nonexclusive commumities of two to ehcit chents' thoughts manages to escape the danger of inadvertent partisanship, she runs another risk - of acquiring dommance over the members. I have touched on this danger already, im criticizing the idea that the lawyer should try to determine her group chent's wishes by carefully interviewing and counsehng each of the individual members separately. The result of that, I suggested, would be to diminish the group members' influence on each other, and enhance the role of the lawyer. ${ }^{99}$ Even if the lawyer tries to use individual sessions ouly as a buttress for later interaction and decision by the members as a group, she may tacitly signal to the members that she is not confident of their ability to decide fairly and wisely for themselves. The more the members come to depend on the lawyer as an intermediary, the more they may concur in this assessment of their own group processes.

The lawyer considering how promment a role to play im the group's interactions should take seriously this danger of inadvertently weakenimg the group members' own sense of responsibility and capacity for dealing with each other. ${ }^{100}$ Nonetheless it must be emphasized that the possibility of direct communication between the lawyer and individual members may be essential to protecting those mdividuals. As one lawyer put it:

97 Clinicians who supervise pairs of students face similar perils if they appear to assess one team member in the course of a meeting with the other-a mistake $I$ have made.

98 Such structures of complementary meetings with opposing parties are used in inediation. See Crime and Justice Foundation, Mediation Training Manual 9-11 (1980) [hereinafter Mediation Traning Manual].

99 See supra text accompanying note 82 .

100 This danger of lawyer dominance will be explored more fully in the following Section. See infra notes 102-114 and accompanying text. 
[There are] some people who are just so beaten down that they are not going to be taking part [im] any process, and we represent a lot of people like that, who have been just through absolute hell time after time, and have been through rotten tenants' associations, they've been through rotten landlords and winters without heat, and this, that and the other thing. Sometimes there are people who are just not going to take part, who are not going to feel empowered, who are not going to try to empower theinselves, and I think that we can't have their opinions and their voices be lost. So it's those people I really try to get involved with on an individual basis. ${ }^{101}$

This comment points to the members' individual needs; these needs inay be all the greater if the group's characteristic ways of functioning pay hittle heed to the silent voices around the table.

In short, the lawyer for a group faces a painful dilemma in seeking to build a community encompassing herself and her chents: the very techniques that may be inost effective in building such ties with individual chents may damage her connection to the chent group as a whole. To some extent, as the discussion in this Section has reflected, the lawyer can "spht the difference," employing such tools as individualized expressions of einpathy in somewhat muted, but hopefully still efficacious, form. But to some extent the lawyer forging a relationship with a group client will likely need to look to other, distinctively group-focused, techniques to win her client's confidence. Among these techniques, I suggest, will be the approaches delineated in the Sections to come, approaches by which the lawyer can both enhance the group's functioning so as to diminish the need for her special intervention witl particular members, and build her relationship with the group so as to enjoy more latitude for intervention when it is needed.

\section{B. Identifying Relevant Considerations}

The bond between lawyer and chent fuels, and is fueled by, the heart of client-centered counseling - the careful, even elaborate, process in which lawyer and chent work together to identify the relevant considerations on which the decision should be based. ${ }^{102}$ This process makes sense only if it is believed that people are prone to overlook or

101 Interview with Judith Whiting (Oct. 1, 1991) (transcript at 30, on file with the author).

102 See generally Lawyers as Counselors, supra note 74, at 287-308 (chapter on "Implementing the Basic Counseling Approach"). 
misjudge important issues bearing on their decisions, and that correcting such errors is an essential predicate to their making decisions that truly serve their own interests. Thus it may be surprising to recognize that it is both unwise and impossible to achieve as exhaustive a coinpilation of the relevant considerations in a group context as in individual counseling. Group discussions inay produce more complete assessinents than any one individual and his lawyer could, because the members' diverse perspectives will illuminate each others' judgments. But these discussions will not be likely to ehicit so many of the particulars of the several members' perceptions and situations as 1night be brought out during a meeting between a single chent and his lawyer. Nor will the lawyer, on whom both individual and group chents must rely for inforination about consequences beyond their expertise, be able to speak to each uncertainty of each of the group's ineinbers. There simply are too inany perceptions, witl too inany nuances, for such exhaustiveness to be achieved. The effort to achieve this, in addition, might actually be counterproductive, for the multiphication of details could serve more to confuse than to clarify the fundamental issues at stake.

Moreover, this is not simply a problem of sheer numbers. For a consideration to achieve notice by the group, it does not need majority concurrence, but it does need to attract attention in the inevitable interpersonal patterns of recogmition and approval that develop within any group. These patterns need not be pernicious; on the contrary, it seems entirely proper for groups to accord respect to those of their members who earn it. At the same time, however, such patterns frequently do not foster free and equal participation by all members. Some people will speak and not be heard; others will not talk; others will orate at length.

None of this means that identifying relevant considerations should be abandoned in group representation; this step is generally miportant to the decisions of groups of people just as it is to the judgments of individuals, and lawyers for groups should encourage their chents to undertake it. But the lawyer's focus must shift in two respects. First, the goal of discussion must now become the eliciting of the major concerns in the group's thinking, rather than the detailed varia- 
tions. ${ }^{103}$ Much as a teacher hearing two students make related points will assist the rest of the class by linking the two together into an overarching point, so the lawyer for a group inust digest, translate, and summarize somewhat disparate comments into more coherent theines. ${ }^{104}$

Second, the lawyer must work to ensure that the considerations brought out are those of all of the group's members, rather than only those of a dommant few. In this effort, however, the lawyer must be careful to work within the context of the group, so as to avoid transforming her group chent into a series of individual chents. Of course, there are straightforward steps the lawyer can take to encourage some people to participate more actively. The lawyer can, for example, say at the start of the meeting that it is important for all members to speak their minds and hear each other's views; she can make sure that those who have raised their hands get a chance to speak, ask people who have not raised their hands whether they have something to say, and discourage talkative members from chiming in repeatedly before others have spoken at all. She can arrange the chairs for the meeting in a circle rather than in rows to facilitate freer discussion. The lawyer may also find it helpful to talk with individual members outside the group meetings, in order to get a better sense of their concerns and be able to ensure that these members' views get aired. Perhaps the

103 The difference between group counseling and individual counseling on this score is substantial, but not absolute. Even in individual counseling, the lawyer cannot expect to liear every modulation of lier client's thinking. Indeed, Binder, Bergman, and Price propose that "the extent of tlie obligation to explore a decision with a client should be governed by the following standard: In counseling chients, lawyers should provide clients with a reasonable opportumity to identify and evaluate those alternatives and consequences that similarlysituated clients usually find pivotal or pertinent." Lawyers as Counselors, supra note 74, at 275 (enphasis omitted). Robert Dinerstein argues that this standard does not adequately protect clients' interest in autonomous deeisionmaking, and suggests in its stead a duty to "ensur[e] the chient's substantial understanding of material consequences," Robert D. Dinerstein, Clinical Texts and Contexts, Review Essay, 39 UCLA L. Rev. 697, 704-07 (1992) (empliasis omitted) (reviewing Bastress \& Harbaugh, supra note 73, and Lawyers as Counselors, supra note 74), but even this obligation plainly would allow for some oinissions. Nonetheless, the task of identifying the pertinent or material issues witl a group seems bound to call for more limited attention to the details of each individual inember's situation than a client-centered lawyer would provide to those meinbers one-on-one.

104 Carol Liebinan noted the feasibility of such steps for me. These steps are especially necessary if the people coming to a particular ineeting liave not been steadily involved, and so on the one hand may lack information and on the other inay have particular agendas of their own that do not fit with the concerns on which the group is now focused (possibilities James Liebinan helped ine identify). 
lawyer will also want to express her endorsement of the significance of points raised by less influential group members, so as to add the weight of her influence to that of the speakers. ${ }^{105}$

These steps may seem innocuous enough. In fact, however, the more the lawyer utilizes them the more she will be taking over leadership of the particular meeting and perhaps of the group itself. The lawyer becomes imcreasingly responsible for decidimg who speaks in the meeting; she also becomes increasingly involved in taking the pulse of the members outside the meeting. These are leadership functions, and the lawyer who takes them on fills a role that group members otherwise might have played. They may also have controversial imiphications, for the patterns of speech and silence within a group are not accidents but rather the product of the interactions group members have had with each other. The lawyer who helps a silenced member to speak empowers him, but she may be undercutting someone else. The very steps that help the group to make decisions, and to realize its autonomy, thus become sources of threat to its self-governance and its internal norms, both of which are also aspects of the group's autonomy.

This dilemma can be eased where the lawyer is able to assist the group's own leadership to open up the channels of communication. ${ }^{106}$

105 Though such patterns of unequal influence anong group members are hard to eradicate, some groups are deeply committed to challenging thein. One lawyer who represented such a group, made up of woinen challenging employment discrimination, described how the members worked to bring out each others' voices:

[A] the [defendant's company] I can think of two clients, both of whoin were incredibly timid people, who had to be encouraged and carried along by the women's caucus in work, and were encouraged to get up and speak at one ineeting after another meeting, only to the extent they could. And I remember an early meeting. They got up and said, "Hello, my naine is so-and-so, and I'm in the thus-and-so departınent and I'm really going to try to hang in there because I think things are pretty bad." And they sat down. But that's all they could do. And after every one [of] these meetings, the women who were the leadership of the caucus would go over to those women and hug them and clap them on the back. ... They really were brought along by the group, and ultimately, I suspeet, for those women, what they got out of the hitigation was this comradeship, this sense of self, this developing sense of personal importance.

Interview with Harriet Rabb (Aug. 29, 1991) (transcript at 34-35, on file with the author).

106 This was, in effect, how the lawyer quoted in supra note 105 characterized her work. When I suggested that she herself must have contributed to her chents' cominitinent to helping group inembers find their own voices, she responded:

Well. I did what the other women, what the women in the caucus would do .... [C]all them, talk to them, pay attention to them, encourage them to speak, encourage them to talk to others, quietly, in whatever way they could, in their own departments, about 
Assuming the leaders do speak for the group, and assuming the lawyer can persuade them, without resort to manipulative or coercive pressure, to take steps fostering wide participation, the steps they take will enjoy a democratic imprimatur traceable to the group itself. As a rule, such steps will probably be forthcoming, for few group members will be likely to insist on the virtues of silencing some of their fellows. Probably, however, there will also be exceptions to this rule-situations, for example, where the majority of group members are willing (or eager) to control the group's decisionmaking with as little input as possible from a minority segment that they see as hopelessly irrational or disruptive. In some of these situations, the majority may even be right!

In tlie most intractable of these situations, the conflict between what will empower the group and what will empower particular members within the group may be mescapable. This conflict is an issue of ethics as well as of technique. I have defended the principle of group representation on the ground that, in addition to giving expression to the potential values of group connection, such representation also increases individuals' power over their lives and vindicates the exercises of individual autonomy entailed in group membership. Here, however, supporting the group undercuts the autonomy of certain individuals. Such conflicts are, I suspect, endemic to group representation, on questions ranging from whether to draw out or submerge a dissenting voice, to how to make an ultimate decision in hight of the conflicting preferences of the members. It is important, therefore, to have a metliod of resolving these dilemmas.

Two such methods seem unacceptable. One alternative would simply, and automatically, favor individual autonomy over group needs (or vice versa). That response, however, would be at least in tension with the premise of this Article that both counection and autonoiny should be honored. ${ }^{107}$ Moreover, if the issue is framed simply as a choice between the autonomy of one person and the autonomy of many (the dissenting minority as against the group's dominant majority), I do not understand why one person's autonomy is necessarily

what was going on and what were we trying to accomplish. It was really what the other women were doing. I did [concur] in it. I did participate in it. But I didn't take responsibility for it. They did it themselves.

107 See supra notes $13-20$ and accompanying text. 
more valuable than many people's, nor why the wishes of many should always override the voice of a single mdividual.

A second alternative would escape the need to resolve these questions by giving the lawyer the prerogative to favor those group members-be they in the majority or the minority-whose position the lawyer feels is more just or more sensible. Although this rule is selfevidently an authorization for lawyers' exercise of power over their chents, it cannot be rejected simply on that gronnd. The reality is that because legal services for disadvantaged people are so scarce, lawyers have hittle alternative but to exercise substantial discretion in choosing which cases they will take and which they will refuse. ${ }^{108}$ Certainly public interest lawyers regularly make decisions about the objectives they will pursue, and declime to take cases not fitting those objectives. ${ }^{109}$ Such practices can also be regarded as exercises of power over clients, who may be pressed to recast their grievances and concerns to fit the lawyers' mold.

Even assuming that we generally accept the propriety of this sort of pressure, ${ }^{110}$ however, that acceptance does not provide a sound rationale for lawyers' intervention in the decisionmaking process of their chent groups so as to systematically favor those views they prefer over those they dislike. Lawyers' decisions to refuse cases not to their liking can be defended as expressions of the lawyers' own autonomy, and the resultant pressure on disadvantaged chents explained as

108 On the shortage of legal services, and the resultant need for lawyers' exercise of discretion in choosing cases, see supra notes 9-11 and accompanying text. For discussion of how this discretion should be exercised, see, e.g., Luban, supra note 1, at 293-391; Bellow \& Kettleson, supra note 10, at 342-62; Ellmann, supra note 11, at 170-89; Paul R. Tremblay, Toward a Community-Based Ethic for Legal Services Practice, 37 UCLA L. Rev. 1101 (1990). These writers' views are not identical, but all of us would accord lawyers considerable authority to take or reject cases on the basis of the cases' impact not only on the client but on the larger disadvantaged community. For a largely dissenting view on this score, see Marshall J. Breger, Legal Aid for the Poor: A Conceptual Analysis, 60 N.C. L. Rev. 282 (1982) (arguing, albeit not without qualification, that "a person cannot be rejected as a client because of the comparative social utility of his case").

109 See, e.g., In re Primus, 436 U.S. 412 (1978) (solicitation on behalf of ACLU to challenge sterilization of black women); NAACP v. Button, 371 U.S. 415 (1963) (NAACP solicitation of school desegregation plaintiffs).

110 To say that some pressure is unavoidable is not to say that all such pressure is acceptable. David Luban, for example, argues that unless lawyer and client are bound in political comradeship the lawyer should not condition her representation of a client on the client's agreement to abide by the lawyer's political priorities. Luban, supra note 1, at 337-40; see infra note 132 . 
a product of scarcity of legal services beyond the lawyers' power to rectify-but interfering with the chent's dehiberative processes does not fit easily with either of these defenses. If the lawyer is only prepared to take a case on particular terins, she should say so, but she should not then prevent those members of the chent group who dislike those terins from having their say, or from having their views counted in the group's ultimate decisions. The lawyer who acts in these latter fashions is doing more than pressuring her clients; she is preventing thein from thinking through their response to her pressure. I do not mean to argue that the lawyer must altogether abstain from steps that shape her chents' decisionmaking in ways they might not have chosen on their own. ${ }^{111}$ Interventions as blunt as silencing or not counting the views of soine group meinbers, however, constitute a drastic interference with those individuals' autonomy and with the essence of deinocratic group association as well, and they should rarely, if ever, be permissible.

Instead, I suggest a third alternative: that the lawyer should consider herself responsible for assuring a baseline of deinocratic and participative process within the group, but that beyond this baseline she generally should not override the arrangeinents evolved by the group itself. Concretely, in the context of identifying relevant considerations, this baseline might require the lawyer to encourage silent meinbers, during the meeting, to speak their uminds. If she felt that the leaders of the meeting were systematically refusing to call on soine meinber, she might have to bring him imto the discussion herself. But she would not have a mandate to make the group's processes "perfect"; often her role would be only to suggest, and not to insist upon, further refinements of the group meinbers' ways of interacting. Rarely, if ever, would she have the right simply to usurp the role of the group's own leaders, for example by invoking her status as the lawyer to justify taking over the chairing of the group's discussion.

This baseline leaves groups with broad, but not unlimited, discretion to shape their own patterns of interaction. The breadth of the discretion reflects the ambiguity of any effort to calculate what mix of

111 On the contrary, I urge lawyers to guide their group clients' decisionmaking in various ways, for example by assuring the baseline level of democracy and participation to which I refer in the text below. Broadly speaking, the interventions that I urge are less destructive of client choice, and better grounded in what are likely to be the clients' own democratic norms, than the abrupt limitations on client voice that I disapprove here. 
group effectiveness and individual voice will maximize the autonomy of the members or the value of the group to them. The limit on it reflects the likelihood that incomplete debate and abrupt dismissal of minority views will generally fail to produce decisions that serve anyone's imterests ideally. For the lawyer to act on this proposition is im a sense simply to act on the democratic norms to which the group is probably to some extent committed already. ${ }^{112}$ But if the lawyer's insistence on a baseline of democracy goes beyond what the group can be said to have consented to, her intervention might still be justifiable as a relatively modest paternahistic imtrusion, meant to protect the group as a whole from the dangers of imternal tyranny. ${ }^{13}$ Perhaps more fundamentally, this intervention can also be justified on the basis of a proposition consistent with this Article's emphasis on the values of both autonomy and coimection: namely, that the lawyer is responsible for securing some protection for imdividual autonomy within the groups of which the individual is a part. For a person's membership in groups from whose decisions he dissents to be an expression of his individual autonomy or selfhood, he generally must, at least, have an opportunity to be heard within the group's councils. ${ }^{114}$

\section{Choosing a Decisionmaking Process}

As important as identifying the relevant considerations is, this inevitably incomplete effort does not play the same part in group judgments as it does in mdividual decisionmaking. In the description of chent-centered counselimg by David Bimder, Paul Bergman, and Susan Price, the central function of the lawyer is to help the chent to

112 See supra notes $85-87$ and accompanying text.

113 In suggesting that this imtervention could be justified as a form of paternalism, I am implicitly relying upon a "sliding scale" test of the justifiability of paternalism, in which a relatively modest intervention, such as this one, can be justified on the basis of considerations that would not support more drastic intrusions. For an examination of paternalistic rationales for lawyers' manipulation of individual clients, see Ellmann, supra note 74, at 764-73; for an extended discussion of legal paternalisin, and the suggestion of stringent standards to govern it, see David Luban, Paternalisin and the Legal Profession, 1981 Wisc. L. Rev. 454.

114 There are exceptions to this proposition, inodest as it may seen, for not every group does adhere, even half-heartedly, to democratic principles. Thus a lawyer who represented a rehigious group seeking to protect its members' rights of free exercise in prison, for example, would not be justified in pressing for participatory discussion by the group's members if they believed that their leader spoke with a divine mandate. Those who voluntarily join such a group have expressed their autonoiny by accepting the group's limits upon it. 
arrive at a full identification of goals, of potential solutions, and of the solutions' pluses and minuses. ${ }^{115}$ Once the chent has this information at his fingertips, often in the physical form of a written hist that the lawyer coinpiled during the counseling, he often, or usually, can make a decision quite straightforwardly. ${ }^{116}$ In the case of groups, however, the difficulties of asseinbling complete information are compounded by the unlikelihood of ever securing unanimous agreement on the proper make-up of the hist of relevant considerations. People may differ over goals (or at least priorities among goals), over evaluations, and even over the relevant underlying facts; an effort to secure agreement on a decision by first securing agreement on all of the underlying considerations may be doomed to failure. ${ }^{117}$

Even more important, the identification of the relevant considerations does not automatically generate a decision. Often this is true even with individual clients, who of course may suffer from doubt and ambivalence that even a lengtliy dissection of the relevant considerations will not dispel. ${ }^{118}$ But with groups the problein is naturally much greater, because even if eacli individual knows his or her mind it reinams necessary for the group to come to a collective decision. To make a collective decision requires a collective decisionmaking metlod, but there is no method that infallibly reflects yet does not influence the preferences of the voters. This conclusion is suggested by two quite different bodies of thought. One is social clioice theory, which argues that we must question the ability of any voting system to reflect accurately the full complex of voter sentiments. ${ }^{119}$ The

115 See Lawyers as Counselors, supra note 74 , at $287-308$.

116 See id. at 308, 347. Binder, Bergman, and Price recognize that soine individual decisionmaking processes "do not run quite so smoothly," id. at 347, and devote a chapter to these bumpier cases. Id. at 347-61. Even so, their account may suggest that typical individual decisionmaking is more straightforward than it is. See Dinerstein, supra note 103, at 715-16.

117 Thus in mediation it may be a serious mistake for the mediator to become entangled in sorting out the facts of the parties' controversy, rather than helping them to sort out the elements of a solution. See Mediation Training Manual, supra note 98, at 39-41.

118 Binder, Bergman, and Price discuss a number of techniques a lawyer can use with chients who find it hard to make a decision even after the normal counseling process has run its course. See Lawyers as Counselors, supra note 74, at 350-56.

119 See, e.g., Richard G. Niemi \& William H. Riker, The Choice of Voting Systems, 234 Sci. Am. 21 (June 1976). For an overview of social choice theory by two of its critics, see Pildes \& Anderson, supra note 81 , at $2128-40$.

Social choice theory seemingly supports a radical skepticism about the degree to which collective, legislative decisions reflect legislators' sentiments. I have argued elsewhere that such thoroughgoing skepticism is hard to square with the intuitive sense that over time 
other is the social psychology of groups, which presses us to recognize that the process of interaction leading up to a decision will influence the einotional attitudes of the group members towards each other, and towards the alternatives of compromise and conflict. ${ }^{120}$

In this light, the selection of a method of decisionmaking is a challenging task. ${ }^{121}$ Before the lawyer can undertake this task, however, she faces a prior question: whether she, or the group itself, should choose the inethod. This is a potential question in the counseling of individual chents, a question that Binder and his colleagues appear to answer by endorsing the lawyer's responsibility for designing a deci-

decisions of democratic legislatures do tend to reflect dominant sentiments. See Stephen Ellmann, In a Time of Trouble: Law and Liberty in South Africa's State of Einergency 30 (1992). Moreover, legislatures do not actually exhibit the randoin unpredictability that could be generated by deeisionmaking processes whose relationship to underlying sentiments was arbitrary. See Daniel A. Farber \& Philip P. Frickey, Legislative Intent and Public Choice, 74 Va. L. Rev. 423, 429-30 (1988). It seems likely, in addition, that the difficulties of capturing group inembers' sentiments in any given voting systein can be amehorated when the groups are sinall enough to allow meinbers to express their views in a variety of contexts besides the formal vote.

Pildes and Anderson, however, offer an additional response to the challenge of social choice theory, a response that inakes a virtue of what surely are the potential guiding effects of decisionmaking processes on results. They inaintain that "social institutions, including democratic ones, must play an active role in structuring individuals' preferences to enable those preferences to rationally express the diverse values that individuals actually experience and affirm." Pildes \& Anderson, supra note 81, at 2142; see id. at 2176-83. Ultinately, they urge the design of deinocratic institutions "to promote dehiberative rationality," id. at 2193, in which collective judgments emerge from a process of secking "shared reasons for collective action," id. at 2201. This enterprise echoes and seeks to give concrete shape to republican aspirations, as the authors recognize. Id. at $2128 \mathrm{n} .23$. It also resembles this Article's aspiration, which is to describe a lawyering role that will foster the democratic functioning of client groups. In encouraging lawyers to assist groups in inaintaining both collective purpose and attention to individual views, iny recoinmendations for group chent-centeredness are incant, like the suggestions of Pildes and Anderson, to affeet group dehiberations, and to do so in accordance with judgments about the desirable shape of these group processes.

120 For a telling exainple of a meeting whose design was unwittingly calculated to generate dissension and frustration rather than to foster agreeinent, see Rodney W. Napier \& Matti K. Gershenfeld, Groups: Theory and Experience 431-33 (4th ed. 1989), a book to which I am indebted. (For a cogent argument-not couched in social-psychological terms-that the choice of an electoral system can play a inajor part in harmonizing or accentuating ethnic conflicts in entire societies, see Donald L. Horowitz, A Deinocratic South Africa?: Constitutional Engineering in a Divided Society 163-66 (1991).)

121 Broadly speaking, "inethods of decisionunaking" embrace not ouly voting systems (or other devices for inaking final choices) but also the processes of discussion and reflection that lead up to the actual decision. Thus, as we will see, even such a seciningly inundane step as the effort to elicit the relevant considerations refleets a judgment about decisionmaking inethodand a potentially contestable one. 
sionmaking process. ${ }^{122}$ This answer risks breaching imdividual clients' autonomous prerogative to decide low they will decide, for a client might want to implement an imipulsive decision, only to be stymied by his lawyer's intention to take him througl an extensive examination of the relevant considerations first. Usually, lowever, clients are probably quite ready to accept the wisdom of a considered process of decisionmaking - if they are disposed to give any thouglit to the question of process at all-and so the lawyer's adoption of the client-centered approacli will meet witl no objection from the client. ${ }^{123}$

When the client is a group, lowever, the clioice of decisionmaking metliod cannot so routmely be made by the lawyer. One reason for liesitation is the slieer uncertainty about what clioice would be correct, but an equally serious problein is that the lawyer who inakes this choice is exercising a form of power over the group. Althougli this is true in the case of individuals as well, the lawyer's intervention is likely to be relatively inore visible when the client is a group, because the shaping of voting alternatives and selection of a voting system will often be more notable events than the process of elucidatimg relevant considerations that is the essence of the decisionmaking metliod with an individual. Many clients surely take the appropriateness of an exploration of pluses and minuses for granted; fewer miglit assume, especially if disagreement were heated, that the selection of the riglit group decisionmaking steps was self-evident. And the members of a group would be particularly unlikely to make sucli an assumption if they already had a decisionmaking structure in place or in mind.

122 Their stance is reflected in Lawyers as Counselors, supra note 74 , at 359-61. See Ellmann, supra note 74 , at 750-53 (pointing out the pitfalls of this approach).

123 I am inclined now to accept lawyers' efforts to engage even reluctant individual clients in this deeisionmaking process as justifiable. Cf. Jolın K. Morris, Power and Responsibility Among Lawyers and Clients: Comment on Ellmann's Lawyers and Clients, 34 UCLA L. Rev. 781, 807 (1987) (arguing that lawyers should structure client decisionmaking). Where the lawyer persuades such a chent of the wisdoin of her preferred process by rational argument, she has done no more than to carry out her obligation to advise her client. Even where she trades on the authority and status of her role as lawyer enough to be fairly described as engaged in a modest degree of paternalism, I would consider such a limited intrusion justified by the likely benefit to the client, and by the possibility that the client's own initial preference for a less deliberative process is the product of soine form of impaired judgment-for example, of einotional distress brought on by the very problem whose legal implications the client is trying to address with the lawyer. 
With a group of this sort, the lawyer may be unable, as well as illadvised, to impose the decisionmaking structure of her choice. ${ }^{124}$

At the same time, the lawyer who wants to help her client group to make decisions, and would prefer to have the group decide how its decisions will be made, must recognize that group discussion of decisionmaking method may be very difficult. The choices to be made have the peculiar properties of being both important and obscure, for method may determine results yet few people are experts on inethods of group decision. Both of these properties perhaps make such issues potentially divisive and entangling as well; those who have seen groups wranghing over procedural issues may be familiar with this danger.

In addition, soine of these choices may be particularly hard to discuss because their impact is subliminal. A lawyer cannot explore with her chient how she will phrase her interview questions about the events that brought him to her office, because the choice of phrasing affects the answers given and discussion of the choice would undercut whatever effects the lawyer seeks through her phrasing. ${ }^{125}$ So, too, it might be self-defeating to discuss with a fractious group whether to arrange agenda items so as to give the group soine experiences of successfully handling issues together before they reached the inost con-

124 Cultural variations in decisionmaking styles can be dramatic. Consider, for example, the "Samoan Circle model, whose central feature is that it is leaderless," as described in Napier \& Gershenfeld, supra note 120, at 450. Adapted for use in an American room, this method has the following features:

Seating is in concentric circles; an inner circle of five chairs is arranged around a small round table. All verbal interaction takes place only at the table, and everyone has access to the central five chairs. If all five chairs are filled and someone outside the center wants to speak, that person stands and waits until another person gives up a seat at the table and moves to another row. If some table seats are vacant, the person who wishes to speak sits in the empty chair. The key element in this meeting style is the participants' proximity to each other around the table. This proximity both increases their personal relatedness and reduces the kind of verbal abuse often hurled around the room when inembers remain distanccd from each other.

Id. (In Samoa, "several days of feasting and drinking together may be expected before the discussion begins." Id. at 449.) Decisionmaking methods can be changed, and one culture's methods may be borrowed for use in another, as the Samoan Circle in fact has been borrowed for use in the Umited States, but clients who are accustomed to this, or any other, method of decisionmaking may neither welcome nor always profit from striking imıvations generated by their lawyer.

12s See Ellmann, supra note 74 , at $742-43$. 
troversial questions they faced. The very identification and consideration of this strategy could undercut its effects.

There is no complete escape from these problems, but here, as in the effort to open up opportunities for all menibers' participation in the discussions that lead up to decisions, the lawyer will be wise to place most of the responsibility for shaping decisionmaking methods in the hands of the group's leaders. Sonnetimes these leaders are not officially designated as such, and sometimes the lawyer may need to encourage the group ineinbers to choose leaders (a choice that unfortunately is itself potentially tainted by process flaws). ${ }^{126}$ Once a group has leaders, however, the group's success in achieving its objectives (whatever they may be) depends in soune measure on those leaders being able to act skillfully rather than clumsily. ${ }^{127}$ If choices of agenda and of decisioumaking method must be made, fairly chosen leaders are, in general, better positioned to make those choices in a way that reflects the meinbers' wishes and sensibilities than a lawyer would be-provided the leaders know how to do this. And so the lawyer's job would be, at least ni the first instance, to work with the group's leaders, helping them to identify the relevant choices and offering her advice about what alternatives might be best. In empowering the leadership, the lawyer buttresses the autonomy of the group as a whole.

The obvious problem with this solution is that it may make the lawyer the ally of leaders who are usurping power over their members. ${ }^{128}$ Indeed, the lawyer's moral responsibility nay be even greater

126 One lawyer explained to me that in her representation of tenant groups one of her first steps is to tell the group to pick leaders, with whom she will be able to work particularly closely. Her practice has been to leave the process of selecting the leaders entirely up to the group. Interview with Judith Whiting, supra note 101, at 5-6.

127 The leaders' success is important not ouly to the immediate achievement of objectives but to the members' (including the leaders') growing sense of their own capacities for effective action-an essential element in einpowering the group and its members. In the words of a lawyer with whom I spoke:

I just thought, if I looked tough and sounded tough and talked tough and could give a ... zesty kind of a speech, they'd go away thinking, "Damn! I'in glad that's our lawyer!" And in a way it was empowering to have a lawyer you felt was the equal of the other side's lawyer, but it would be better if they came from mectings thinking, "Damn! We did that well ourselves!"

Interview with Harriet Rabb, supra note 105, at 29.

128 One lawyer described an incident with a trace of this flavor:

A couple of students met with three or four meinbers of a client group, and they were talking about how to get the tenants to do this or that, or to follow a particular course of 
than that, because she may have triggered the group's formal organization and its decision to name leaders. In the long run, the leaders' abuse of power may destroy the group, but plainly its inimical effect on the individual autonomy of the disempowered members is more imniediate. I suggest that here, as ni the case of opening up channels of communication, the chent-centered lawyer's responsibility should be to monitor the fairness of the group's decisioninaking processes, and if need be to intervene on behalf of those who are becoming victims within the group itself. She imght, for example, make plam to each member of the group that she is always available to talk to any one of them individually and in private. ${ }^{129}$ Once alerted to a problem, she might try to resolve it through persuasion of one sort or another-for instance, by privately urging the leaders to adopt particular decisioninaking processes. But she would not attempt to challenge the power of the leadership directly (for example, by trying to override the leaders' decisions in a meeting of the group as a whole, in alliance with the dispossessed ineinbers), unless the methods the leaders were using fell beneath a baseline threshold of deinocratic fairness. Given the difficulty of crafting an objective standard for this threshold, it might be that lawyers' touchstone should be their sense of whether the group's leaders are deliberately aiming at the suppression of a dissenting view.

A lawyer who does try to block the leadership's running of the group imight undercut the autonomy of the group-the ability of the group as an entity to work its will-and so her conduct might seem inconsistent with the acceptance of group representation on which this discussion has been predicated. ${ }^{130}$ To be sure, in some nistances there will be no such conflict at all. It deserves einphasis that if the

action that either the lawyers were suggesting or that the leadership knew was appropriate, and the President [of the tenants' group] said, "Well, they won't listen to me, but they would histen to Jewish guys in suits"; and of course the students were Jewish guys in suits.

Interview with Barbara Schatz (Aug. 30, 1991) (transcript at 8-9, on file with the author). The president's comment arguably invited the students to exercise power over the group-though it may have stigmatized the students at the same time.

129 One lawyer quoted earher gives the inembers of the groups she represents a message on these lines. Interview with Judith Whiting, supra note 101, at 31,35 . She wants the individual members to know "that though I'm representing the group, the group is coinposed of individuals, and I'm representing each individual ... and not, say, just the tenant leaders." Id. at 34 .

130 Such conduct surely will increase the lawyer's influence over the group and its members. 
group's leaders are trying to override the wishes of the majority of the group's members, and the group embraces democratic values, then challenging the leaders is entirely faithful to the autonomy of the group as a whole.

Sometimes, however, the group's leaders may be giving voice to the majority sentiments of the members, and then the conflict between group autonomy and individual autonomy is more starkly posed. As in the case of participation in discussion, so in the case of decisionmaking itself, I suggest that respect for mdividual autonoiny and selfhood does justify limited intrusion on the autonomy of the group. Where the group asserts its fidehity to the principle that each person has an equal say in decisionmaking, but its leaders are atteinpting to suppress the views of a minority, the lawyer should consider it her duty to vindicate the principle of fair process even over the opposition of the group's majority. ${ }^{131}$

\section{Encouraging Group Harmony Around Decisions}

The lawyer who counsels an individual chent wants to help that chent to make a decision that he can live with, both because such a

131 This principle will not hold, however, for at least some groups that do not claim to embrace democratic values, because the autonomy and selfhood of the individual members of these groups may not rest on having an equal say in decisionmaking. Religious groups may be one such example, see supra note 114 . The family might be another. Families are commonly not governed on democratic lines; although this is not always cause for rejoicing, probably most people approve of parents' efforts to exercise a bemign rule over their growing children. To challenge this parental authority would be a blow to the family's autonomy, and normally, I suggest, an unjustifiable one. Thus, for example, a lawyer representing a homeless family would be quite wrong to routinely challenge the parents' preferences for potential shelter placenents based on contrary wishes of the children, however articulate the children might be. But she might well be justified in taking such steps where the parents' governance had degenerated into neglect of the children's welfare. She might also be justified more generally in pressing the parents to allow the children an opportunity to speak their minds.

On the other hand, there are likely to be cases in which a lawyer shonld argue for egalitarian decisionmaking despite the group's disavowal of this ideal. So, for example, a lawyer representing a married couple, both of whose members declared that a particular decision was up to the husband because he was the "head of the family," might urge the spouses to see the particular decision on which the lawyer has becn consulted as one that should not be left up to the husband alone. Cf. supra text accompanying notes 68-73 (discussing the example of a married couple making their wills in circnmstances perhaps reflecting the wife's domination by her husband). But I do not think the lawyer could properly insist-im the absence of some legal requirement of egalitarian decisionmaking-that the husband and wife accept her preference for such equal voice uuless she was prepared to deny that women in general, or this wife in particular, could competently choose a marriage on such terms of inequality. 
decision will be better for him and because he will be less likely. to regret or revoke it later (events that may be disruptive for the lawyer as well as the chent). The client-centered lawyer who represents a group should similarly seek to encourage a decision that will "sit well" with the group as a whole. Decisions that the group can live with promote the group's cohesion and strength. Hence they enhance the autonomy of the group and, within limits, the autonomy of the members. To some extent, groups may be able to take heart from decisions over whicli the members were deeply divided, if every member is persuaded that the process of decisionmaking was a fair one in which he or she was heard and his or her views respectfully considered. Because many people may not be deeply moved by fair process when they feel the wrong decision has been made, however, the lawyer who seeks to foster group coliesion will also have good reason to try to encourage broad substantive agreeinent among the inembers. Yet the goal of encouraging agreement entails ethical problems, as an examination of some techınques by which lawyers might achieve it will reveal.

We might, first of all, consider the path to agreement as essentially a form of negotiation. Negotiated settlements serve all parties' interests if what can be obtained in negotiation is better for each tlian what he or she could obtain elsewhere. But the members of groups represented by public interest lawyers face a severe constraint on what they can obtain elsewhere-namely, the unlikelihood that they could obtain new counsel to represent them in a schismatic venture on their own. They are, therefore, likely to be under considerable pressure to find a solution within the parameters of continued membership in the group. This is undoubtedly a restriction on the individual autonomy of the members. This reality by itself, however, is no basis for lawyers' not seeking consensus among the inembers of their client groups. That poor and disadvantaged people rarely have wide choices of counsel is indeed a blow to their autonomy, but it is not a blow struck by the public interest bar. ${ }^{132}$ This lack of choice is part of the grim

132 See supra notes 108-10 and accompanying text. Public interest lawyers can, lowever, exploit their clients' lack of alternative counsel in ways for which the lawyers must bear responsibility. The more a lawyer presses her clients to adopt priorities that slie herself lias set, and the more clients yield to sucli pressure because they cannot escape it, the greater the cost to their autonomy, whether as a group or as individuals. I will argue that there is nonetheless room for lawyers to urge their own views on the groups that they represent, see infra notes 
truth of such clients' social position, and is one reason why collective representation is appropriate in these cases. That the members of groups needing collective representation are also constrained by it is simply unavoidable.

The process by whicl the "negotiating" members find common ground, however, is not simply one of rational exploration. Instead, it also imvolves emotional orientation. The lawyer who wants to encourage agreement ainong tlie members may devote much of lier effort to providing the members with a largely emotional reassurance about the possibility of agreement. Her role tlius begins to be tliat of a mediator, and it is useful to consider some of the steps that mediators may take to lielp disputing parties to find common ground. ${ }^{133}$ For exainple, one mediation manual advises:

From the very outset of the private sessions, the mediator needs to stress positive aspects of the negotiations and reassure the disputants. Most basically, stressing the positive involves the mediator manifesting optimism about the likelihood of reaching an agreement. A casual comment to each disputant might stress the fact that both parties seem like reasonable people who are sincere about resolving the situation. It is also a good idea for the mediator to review points with each disputant where there seems to be a basis of agreement. Even in the inost difficult dispute, such common ground can be found. After all, both parties agreed that mediation might be a good idea. . . . A central aim of the mediator is to create a constructive momentum toward agreement. As the mediator shuttles from one private session to another, (s)he should diplomatically comment that the other disputant is also sincerely working hard at building an agreement and hopes that further conflict may be averted. ${ }^{134}$

149-63 and accompanying text. In the present Section, however, I am concerned only with lawyers' efforts to assist the members of chent groups to bridge the gaps between the various views of the members themselves-a task in which the danger to the members' autonomy is somewhat mitigated precisely because no injection of any third party's preferences is involved.

133 Barbara Schatz and Carol Liebman called iny attention to the relevance of mediation techniques.

134 See Mediation Training Manual, supra note 98, at 38. Later,

[a]s points of agreement begin to come out ... [the mediator] should also keep reviewing these. When reviewing areas of agreement, the mediator should stress how these represent the positive frnits of each disputant's hard work. Stressing the positive must continually be done if the negotiating momentum is to be maintained.

Id. at 41. 
Besides encouraging each party about the other, and about the progress being made, the mediator may also find it helpful to reassure each disputing party about himself (and, imphcitly, about the mediator's positive attitude towards him). Thus, according to the same manual:

Reassurance is a technique, which if exercised skillfully, contributes significantly towards the momentum to settle. The mediator should compliment each disputant's sincerity, reasonableness and patience. A disputant should also be complimented on his/her good judgment at deciding to participate in the mediation process. . . . A disputant should be reassured at times when it may help to soften a position or as positive reinforcement to a positive decision. ${ }^{135}$

Techniques such as these obviously rely heavily on the impact of what the mediator or lawyer says to the disputing parties. Strong incentives towards agreement may also be generated without explicit exhortations, if the decisionmaking process is shaped so as to bring people togetlier ratlier tlian pushing tliem apart. Parliamentarians may be dismayed to encounter the suggestion that Robert's Rules of Order, because tliey are "based on debate," einbody a "constant tendency toward polarization."136 So, too, decisions based on simple majority voting may leave a large minority feeling that it lias been the victim of "control and mampulation by tlie majority." 137 A decisioninaking approacli meant to encourage agreement miglit take quite a different form, as in this sclieme for resolving an issue dividing a university department's faculty:

State the problem and a history of the issue to this point in time. Next, reach agreement that at the following departmental meeting a decision would be made that would be tried for six months and then reopened for discussion. Define the condition that a 60 percent vote would be required to change the present system. Randomly create some groups of three or four and give each group 20 minutes to develop two alternatives to the present situation. After 20 minutes, combine the six groups imto three groups of six and ask each to nego-

135 Id. at 38. The manual also suggests that "[s]ometimes such comments should be made even though a disputant does not completely deserve them." Id. This suggestion is plainly manipulative, though it may be justifiable, for example on the ground that it is a necessary element of psychological support to someone otherwise emotionally disabled by the stress of the dispute.

136 See Napier \& Gershenfeld, supra note 120 , at 360.

137 Id. at 353. 
tiate a single best solution in 30 minutes. Then ask a inember of each group to present the idea of his or her group to the total group. Ask the members to discuss these ideas during the period between ineetings (one assumes considerable discussion would ensue) and take a vote at the beginning of the next meeting. If the group cannot reach a 60 percent majority at that time, discuss the two favorites for a limited amount of time. If a 60 percent vote cannot be attained, then use the system presently in vogue for a period of six months. ${ }^{138}$

All of these processes share a common focus on putting the parties in the right frame of mind for agreement. They all share, too, the potential that they will so powerfully affect the parties' feelings as to generate agreements that the disputants would not have entered into if they had not been filled with the spirit of the moment. Moreover, although these steps are not covert they do seem to tap into aspects of people's feelings-their need for recognition or reassurance, their desire to please and to get along with each other-that are not entirely conscious and are therefore particularly hard to resist. In short, these techniques seem to put the imdividual autonomy of the disputimg members in jeopardy, by subjecting them to blandishments and processes designed to ease them into agreement.

If violations of individual autonomy could be justified simply on the grounds that group autonomy took precedence, these techniques' impact on mdividual autonomy might be of little consequence, but I have rejected any such automatic favoring of group over individual concerns. Nonetheless I suggest that lawyers can be justified in urging the groups they represent to follow such processes. They may be justified, first, on the basis of consent from the group's leaders or members. Such consent may be express. When lawyers urge groups to proceed in such ways they can, and should, make clear that the methods they propose are designed to encourage people to come to agreement if they can. After such an explanation, the leaders of a group (or its members) might give a specific consent to particular steps, or they might give a general approval to the idea of trymg to foster agreement, an approval which could reasonably be seen as consent to some range of particular steps meant to provide such encouragement. Moreover, people who join a group usually do so with some desire for the harmony of the group they are entering. Group mem- 
bership itself may therefore be taken as signalling some degree of implicit consent to steps that will help the group to stay together.

Neither of these consent arguments, however, is entirely satisfying, because the lawyer may not be able to explain soine of the techniques that she will use without defusing their effects. ${ }^{139}$ She could hardly announce in advance, for exainple, that she would be coinplimenting the disputing ineinbers when she felt that doing so would encourage them to make new concessions. Nor can it be assumed that group meinbers take for granted that their lawyers will try to hold the groups together in these ways. To be sure, the lawyer imight be able to make full disclosure to the group's leaders, and win authorization from thein for the approach she will take with the group as a wholebut the leaders' authority to subject their meinbers to manipulation may well be questioned, and in some cases the leaders theinselves may be embroiled in the very disagreenent the lawyer hopes to ease. If the justification for such methods turned solely on consent, therefore, lawyers imight often have to forego, or at least curtail, their use of certain potentially valuable tools.

We are left, therefore, with the question of whether the intrusions on individual autonomy that consent does not dispel can be justified by the enhancement of the group as a whole. I have argued that such justification cannot be automatic; it can, however, be contingent. In some circuinstances, that is, a gain for the group as a whole can justify a paternalistic interference with the autonomy of its meinbers. This is a potentially pernicious argument, susceptible to immense abuse, yet it is hard to deny that sustaining the group can in soine circuinstances benefit even its more reluctant ineinbers.

Accordingly, lawyers contemplating the use of such techniques must niake a judgnient about their impact, a judgment that takes into account the daniage that may be done to individual autonomy and the benefit that may accrue to the group as a whole. This judgment would, I suggest, often favor the use of these techniques. Relatively intractable disagreements niay both grow out of and fuel strong emotions that distort the members' own assessinents of whether, and how, to restore harmony-even though the niembers remain presumptively

139 She might also use these very techniques in the process of gaining group consent to her further use of them! So, for instance, she might compliment the group's members on their desire to reach a harmomous decision in order to encourage them to adopt a decision process that would further press them towards agreement. 
competent adult decisionmakers. Moreover, the violation of individual autonoiny that these methods work seems relatively modest, especially given the partial consent that may also buttress their use. So, too, the likelihood that requiring the members to give an informed advance approval to certain techniques would undercut their efficacy appears significant, and the value these techniques may bring potentially substantial. ${ }^{140}$

Sometimes, however, the balance of imterests will he the other way. To make this balance the lawyer will need to look carefully, and as objectively as she can, at the nature of the division of views within the group. The more profoundly the group is divided, the less appropriate it will be to keep the inembers together. The more feasible it would be for each portion of the group to pursue its own views, again the less appropriate it will be to impose a process that preserves unity. And-last but not least-the lawyer should seek to gauge the members' actual commitment to the group; the less it is, the less justification she has for bolstering it subliminally. ${ }^{141}$

\section{E. Responding to the Group's Disunity}

In a variety of ways, the steps of chent-centered lawyering for groups that I outline in this Article risk the diminution of dissenting voices within chent groups, whether because of interaction patterns or voting systems that undervalue some inembers' contributions, because of harmony-fostering techniques that seek to defuse disagreement, or because of the persuasive impact of the partisan advice lawyers may give. ${ }^{142}$ I have also sought, however, to preserve for all group members basehne protections of their mdividual autonomy. If this goal is to be achieved, the chent-centered lawyer must be prepared to recognize and respond to those situations in which the group-supporting techniques she normally uses may no longer be appropriate, because the group has become so riven by disunity.

140 The conclusion that these factors demonstrate the propriety of modestly paternalistic interventions by the lawyer relies on the "shiding scale" approach to paternalism that I have already endorsed, see supra note 113 .

$141 \mathrm{Cf}$. Simon, supra note 12 , at $481-82$ (suggesting considerations that could justify keeping a class together despite profound differences of view within the class).

142 I take up the impact and propriety of lawyers' advice in the following Section. See infra notes $149-63$ and accompanying text. 
The lawyer's task, therefore, is to distinguish between disagreeinents in which all sides remain loyal to and integrated within the group, and those in which the division is more profound. ${ }^{143}$ Suppose that a lawyer represents an African-American parents' group that has brought long-running hitigation challenging discrimination in the pubhic schools. ${ }^{144}$ When the case began the members were quite firmly committed to desegregation as the remedy for this discrimination, but over the years some of the parents have come to beheve that all-black schools with adequate funding will provide a better education for their children than desegregated schools to which the children will have to be bused. For several inonths, the lawyer has sought to help the parents find common ground around a program that would seek some degree of both desegregation and enhancement of all-black schools-but these efforts have failed. The members are divided, both sides see the division as turning on a fundamental point of principle, and the pro-enhancement parents see themselves as without a meaningful voice in the decisions of the group, which remains dominated by a pro-integration majority.

The lawyer's first duty should be to represent the position endorsed by the orgamization, rather than to withdraw from the case altogether. Acting under Model Rule 1.13, the lawyer for a group represents it as an entity rather than its members as individuals, and so the spht among the members does not put her in the untenable situation of representimg clients with conflicting imterests. She does not, and never did, represent the members who now take issue with the organization's position. ${ }^{145}$ That is the view of the Model Rules; it is also im

143 A separate form of disunity would arise if some minority faction within the group were in effect to stage a coup. In that case, as I have already suggested, see supra text following note 130, the lawyer loyal to the group should be disloyal to the usurpers of power within it, and should act in concert with the other members to try to restore their role in the group's affairs. The lawyer's duty in such a situation might be analogous to the responsibility of a corporate lawyer who becomes aware that a self-dealing group of directors has taken over control of the corporation.

144 This is a well-known example of possible intra-group conflict. See generally Derrick A. Bell, Jr., Serving Two Masters: Integration Ideals and Client Interests in School Desegregation Litigation, 85 Yale L.J. 470 (1976) (suggesting that lawyers coinmitted to integration do not truly speak for the black community, many of whose meinbers see pressing for integration as fruitless); Simon, supra note 12, at 481-82 (contending that conflicts among black parents over the desirability of integration might be better satisfied through "intraclass resolution" than through separate representation for parents of different views).

145 See supra notes 36-46 and accompanying text. 
general an appropriate consequence of valuing the representation of people in groups, when-as here-the bulk of the inembers adhere to the group's position, and they control the organization by fair ineans rather than foul. To bar the lawyer from continuing to represent the group when its members are severely at odds with each other would make the representation of groups as groups a constantly endangered undertaking, and could profoundly impair such bodies' ability to survive the inevitable risk of schism.

But the group originally consisted of both the majority meunbers and the minority, and the dissenters' autonomy is now in peril: they are an alienated, and seemingly voiceless, minority within the larger group. I suggest that the lawyer has soine duty to help thein get their voices heard if they so desire. In particular, this means that the lawyer should ask them whether they want to pursue on their own the issue over which they have argued with the majority, and if they do, the lawyer should advise them to get counsel. ${ }^{146}$

This responsibility is less inodest than it may seem, because embedded within it is a further task: the lawyer must judge when a part of the group she represents should be asked whether they want to separate. Raising this possibility may contribute to making it a reality, and the lawyer who represents a group cannot ordinarily be under a duty to encourage its break-up. It is ouly when umity becomes impossible or improper, in light of the feelings and interests at stake, that the lawyer has a duty to recognize the group's fission and help the dissenters to take their leave.

Until then, the lawyer for a group serves her chent well if she helps it to stay whole. Even after the neinbers of the group have developed an unbridgeable difference of views the lawyer can often appropriately urge both sides not to consider this a ground for divorce. Thus it is easy to envision the lawyer for the group meeting with its angry

146 Under Model Rule 4.3, the minority members are, strictly speaking, unrepresented persons, to whom the lawyer may, but apparently need not, give this advice. See Model Rules, supra note 7, Rule 4.3 and cmt.; see also Model Code, supra note 6, DR 7-104(A)(2) (forbidding counsel to give any advice, other than the advice to secure counsel, to an unrepresented person whose interests may conflict with the imterests of the lawyer's client). If the lawyer were representing a class of black parents, rather than an organization, she might have a similar responsibility to call to the attention of the court the existence of a substantial dissenting group, potentially a subclass, within the class. See Rhode, supra note 19, at 1205 (such a responsibility is a principle element of counsel's fiduciary duties to absent class members). 
minority, and urging them not to abandon the group but instead to maintain its collective strength while hoping to win the policy fight another day. In the course of such a discussion, she might even raise the possibility of separation as a way to help prevent it from becoming a reality, for she could hope that as the members of the dissenting group contemplated the imphications of their position they might recoil from it.

The lawyer's responsibility to help irreconcilable dissenters to depart is, then, the counterpart of her responsibility to help other dissenters to reconcile. What she says may determine which category the dissenters ultimately fall into. She may atteinpt to persuade, yet she inust be sensitive to the dissenters' right to choose their own course, and even as she speaks she inust judge her histeners' responses, and try to gauge whether what she hears is an opening for further persuasion or a gathering decision to divorce. In this effort, she is likely to be biased in favor of the unity for which she argues, because that unity is ordinarily in the interest of her group chent. For this very reason, I believe she inust take care to histen attentively for the sigus of an alienation so great that for those who feel it departure is the appropriate step. In doing so she can take into account the importance of the issue, the depth of the differences in views within the group, and the intensity of feehings it lias aroused. But the decision will still be a judgment call, and a painfully difficult one.

If, in the end, the dissenters do leave and obtain separate counsel, normally the lawyer should still continue to represent the group. To require her to withdraw instead would deprive the group of knowledgeable and familiar counsel, perhaps at precisely the time the group needs her assistance inost. ${ }^{147}$ In the context of the representation of the relatively informal, democratic groups on which this Article focuses, however, a relentless application of this principle might sometimes aggravate the harm done by the split itself to the accoinmodation of individual and group interests. This danger seems real, for example, if the spht appears to be the product of dubiously democratic behavior on the part of the majority; if the group is almost evenly divided; if continued representation would in the lawyer's

147 Again, Model Rules, supra note 7, Rule 1.13 would appear to permit the lawyer to remain on the case; indeed, under Rule 1.13, a lawyer for an entity client is so far shielded from a duty to the entity's individual constituents that she can bring suit against a "former constituent" on the entity's behalf. See supra note 45 . 
judgment seriously damage the interests of the minority; and if continued representation would entail the lawyer's using information that minority members gave her agamst the very people who provided it. In some cases, considerations such as these inay weigh so heavily that the lawyer will have to withdraw-despite the immense blow to the group that her withdrawal could strike. ${ }^{148}$

\section{F. Advising the Group-and Allying with It}

The guidelines offered in the preceding Sections have all been meant to assist the lawyer in ehciting the views of the group's inembers, and in dealing with the differences among the members that einerge in that process. Their focus has been primarily procedural, and certainly procedural issues are of great inoinent in group representation. But a chent-centered lawyer must address the substantive choices before her chent as well as the procedures to be used in making those choices. Most prosaically, she inust provide the chient with the information the chent needs in order to inake a decision based on an accurate understanding of the available options and their likely consequences. Somewhat more controversially, she inay tell the chent what she thinks the chent ought to do. Binder, Bergman, and Price now accept-in iny judgment, correctly-the propriety of the lawyer's giving advice, and indeed take the view that "reject[ing] requests for advice . . . deineans chents' ability to make independent judgments." 149 Though they suggest that normally the lawyer should give advice based on the chent's values, discerned through the counseling

148 See Pope, supra note 86, at 39-43 (arguing that union counsel should frequently be disqualified from representing the union or its officers in litigation claiming that the union has departed from democratic principles of internal governance); cf. Hazard \& Hodes, supra note $30, \S 1.13: 602$ (corporation's lawyer may be unable to represent either the corporation or its directors in derivative suits raising charges going beyond "a disagreentent over busmess judgment"). This is a terrible result, lowever, for groups that have hittle realistic chance of obtaining alternative counsel. Perhaps in some cases less drastic remedies could be fashioned (if need be, with amendinents of the rules of ethics to authorize them); for example, if the group and its dissenters seek different, but not inimical, objectives, counsel for the group might be required to make available to the dissenters' counsel all information she gathered front any meinbers, majority or ininority, prior to the split.

149 Lawyers as Counselors, supra note 74, at 279. See supra note 80 (on the treatment of advice-giving by Binder and his colleagues). Such advice-giving should not generally be prohibited even where the chents cannot retain alternative counsel if they dislike the advice they hear-although lawyers in such circumstances should be closely attentive to the possibility that their advice is not enhancing but undercutting their clients' autonomy. 
process, ${ }^{150}$ they also affirm the propriety of the lawyer's expressing her own moral or political perspective when she disagrees with the chient's intentions. ${ }^{151}$ So, too, a client-centered lawyer for a group can give advice based on the priorities the group has articulated during her work with it, and she can speak based on values she holds but that the group inay not. But the imphications of the advice-giving role change in certain respects when the chent is a group rather than an individual.

First, the lawyer will often be unable to take a clearly defined set of client values and give advice that simply applies those values to the situation the client faces. To be sure, individual chents rarely present their lawyer with entirely clear sets of values either, ${ }^{152}$ and the lawyer who tries to give advice based on the chient's values may not so inucli be telling the chient what his values suggest he should do as helping him to reflect further on just what his values are. Nevertheless the lawyer's uncertainty about the chent's values is often bound to be greater with a group client, for a straightforward reason: the group is unlikely to be unanimous about its values. In addition, because of the multiphicity of individual sentiments within the group and the impossibility of fully ehiciting thein, the lawyer often may not achieve as precise a feel for whatever values the group does share as she can attain when she deals with a single individual. As a result, the lawyer may be unable to give advice of the form, "Since you feel this is an inportant consideration, it makes sense to take this action." Instead, her advice may need to be, "If you decide that this is an important consideration, then this action makes sense." Sometimes she will need to add, "But if you decide that another consideration is also important, then a second course of action makes sense." Her advice, im short, may have to be even more tentative than when she speaks with an individual chent, and the role of her advice frequently inay be more to inform further debate than to bring the chent to a quick resolution of uncertainty.

150 See id. at $279-80$.

151 Id. at 282-84. For other endorsements of such moral advice, sce Bastress \& Harbaugh, supra note 74, at 130, 334-38; Shaffer \& Elkins, supra note 74, at 290-319. But cf. Robert D. Dinerstein, Client-Centered Counsehng: Reappraisal and Refinement, 32 Ariz. L. Rev. 501, 561-70 (1990) (urging careful limits on lawyers' advice-giving).

152 Lawyers as Counselors, supra note 74, at 264-65. 
Second, if a lawyer contemplates giving advice based on her own values to a group, she must weigh against the benefit of her advice the risk of contributing to the disunity of the group. As we have seen, the lawyer for a group can have a special responsibility for promotimg group harmony around decisions, a concern that disappears in individual representation. When the lawyer gives advice based on her own values, she inevitably runs the risk of being seen as a partisan, and very possibly also as an ally of one segment of the group against others. ${ }^{153}$ She may then be less able to win the conflicting members' trust in a process, whether of inediation or of structured discussion, that is meant to lead the members to see the logic of each others' positions and find common ground among them. If agreenent is never achieved, moreover, the lawyer may have sacrificed some part of her credit with the dissenters, and thus be less able to assist them in their decision either to stay with the group or to abandon it. ${ }^{154}$

Third, the lawyer who gives advice based on her own values when the group itself does not share those values is not likely to see her views prevail, at least unless she resorts to methods of persuasion that are emotive, and sometimes manipnlative, rather than merely reasoned. It may never be easy for a lawyer to persuade a client to follow her values rather than his own. A group's values represent the confluence of many people's thinking, however, and nuay well be part of the very foundation of the group's existence. The chances of the lawyer's overcoming the group's contrary inclinations seen limited. It imght seem, in sum, that there is hittle to be gained, and nuch to be lost, by lawyers who go beyond giving advice carefully keyed to the values of the group menibers.

When a lawyer gives only this nodest advice and bends her efforts to pronioting group harmony from a stance of neutrality, she is playing a valuable role, but there is another, nuch nore assertive, possible part for the lawyer to take. If the lawyer who gives advice based on

153 This danger would exist if the group members disagreed over values; it would also exist if the members were in some agreement about values, but were argumg over what their shared values suggested they should do in the case at hand. The lawyer who expressed her view about the implications of the group's values could easily become embroiled in the members' dispute over that very question.

154 Although the dangers described in the text are distinctive to group representation, I do not mean to say that lawyers' expression of their own views to individual clients is without risk. For example, the client who hears his lawyer's views, and then rejects them, may resent the lawyer or regret his deeision not to take her advice-or both. 
her own values risks ahenating or dividing the group, perhaps she can partially overcoine these dangers by showing the group members that she in fact shares their core convictions. Then her supportimg one side rather than the other $\mathrm{m}$ an internal dispute might be couched in the context of her fellowship with all of the members, and even her arguing against a consensus of the group might be framed as an argument from a dependable ally rather than from a disengaged critic. To be sure, this visibly shared commitment will not always be a way to preserve credibility with the group's members. ${ }^{155}$ Some groups will be too divided for the lawyer to present herself as everyone's ally, and some issues will be too divisive for disagreement not to be seen as fundamental. In those cases, in fact, the lawyer's more active commitment might even inake her a more divisive force than someone who, however irritatimg, was not seen as directly involved. But in some groups, the more engaged the lawyer is, the greater the impact she may make with her advice. ${ }^{156}$

155 Certainly her expressions of shared commitment will not assist the lawyer if she cannot make these statements themselves credible to her audience.

156 Perhaps this image of a lawyer-client alliance should be taken even further, to endorse not just the lawyer's avowal of the behiefs she shares with the group but her decision to join the group as a member herself. It is not hard to understand why lawyers, hke other people, miglit wish to give such full play to their own behefs and autonomy. In addition, such steps may deepen the lawyer's bond with her clients; as one lawyer who was arrested with his friends and clients has observed, "That I was willing to do the same thing they were willing to do broke down some barriers in terms of trust ...." Creative Defenses in Civil Disobedience Cases, supra note 72, at 106 (comments of Leo Goldstein). At least two colleagues with whom I've discussed these ideas have told me of their own involvement, as members, in groups that they wished to aid.

Nonetheless, I suggest that lawyers often should not become meinbers of the groups they are representing. To do so may interfere with the lawyer's ability to carry out courtroom tasks on the client's behalf. See Model Rules, supra note 7, Rule 3.7 (restricting occasions on which a lawyer can act as an advocate at a trial in which she will also be a witness-as she might if she was part of the underlying events). Outside of court, moreover, such full involvement risks depriving the lawyer of the appearance, or reality, of objectivity that may be essential to her playing the roles of facilitator, mediator, and momitor of group democracy that I outlined earkier. The alliance I describe in the text is one in which the lawyer offers solidarity but mamtains a measure of professional distance at the same time; in many eases, I suggest that this distance will enable the lawyer to provide more valuable legal assistance than she could if she either erased or expanded the gap between herself and her chents.

I do not propose this guideline as an absolute rule. There may well be people who can shape a role as members-cum-lawyers in which they are able to contribute the same sorts of group process facilitation that I envisage more disengaged attorneys supplying-while also sharing the full experience of membership in the group. There may also be groups in which the lawyers maintain membership and hence solidarity, but are not expected to participate in the activities of the group that they advise on, or defend, as lawyers. In addition, there may be 
This full moral engagement between the lawyer and her chent group, however, constitutes a relationship quite different from the characteristic chent-centered interaction. In individual chent-centered practice, perhaps the central emotional bond between lawyer and chent is forged through the lawyer's empathy. Empathy, as Binder, Bergman, and Price characterize it, is the lawyer's nonjudgmental understanding and acceptance of the chent. ${ }^{157}$ Empathy can be a powerful emotion, but it is a bounded one. In theory, at least, the lawyer who displays empathy does not offer actual approval of her client's feelings or behefs, for such approval would be a form of judgment. ${ }^{158}$ Much as chents might respond to positive judgments from their lawyers, a focus on the centrality of empathy seems to weigh against the client-centered lawyer's expression of such approving evaluations. ${ }^{159}$ There is, imdeed, good reason for lawyers to be wary of endorsing what their clients say, for the more a lawyer endorses any particular aspect of what the chent tells her, the less the chent will feel free to reveal other, inconsistent aspects of himself. If the client comes under such constraint, neither he nor his lawyer may be able to identify fully the real considerations facing the client, and so his decisions may be warped by the lawyer's approval. The lawyer who wants her clients to recognize that she shares their central values, however, must convey, exphicitly or imphicitly, just such endorsement or approval. Nothing less will express the sharing that she means to manifest.

groups who will only trust lawyers who forego professional distance, and for whom a lawyer from within their own ranks may therefore play an essential role. (I appreciate the comments of participants in the New England clinical teachers workshop on these concerns.)

157 Lawyers as Counselors, supra note 74 , at $40-42$.

158 Bimder, Bergman, and Price make clear that in their view even approving, judgmental responses are not empathetic. See id. at 60-61. The line between understanding and approval can be an indistinct one, however, and in practice, if not in theory, empathetic understanding nay well shade imto inplicit approval. I explore this and related issues further in Stephen Ellinann, Einpathy and Approval, 43 Hastings L.J. 991 (1992).

159 Binder, Bergman, and Price do endorse approval, or "recognition," of the chent's efforts to commuricate with the lawyer, see Lawyers as Counselors, supra note 74 , at 43 , but this form of approval has nothing directly to do with endorsement of what the chient wants or beheves. The emphasis Binder and his colleagues place on einpathy, and the absence of comparable encourageinent of the use of approval, suggest that these writers believe that client-centered lawyers should normally refrain from einploying the latter teehmique. Bastress \& Harbaugh, supra note 73, offer more, but still hmited, room for approval. See id. at 189. 
In many situations, moreover, clients will insist on such commitment from the lawyer as a tacit condition of retaining her at all. It is inconceivable, for example, that a group of black parents pressing a scliool desegregation case would happily entrust their cause to a lawyer who did not consider segregation a profound injustice. ${ }^{160} \mathrm{~A}$ lawyer who expressed understanding of the parents' position, but never manifested her agreement with their fundamental grievance against the state, would also be more likely to receive the parents' suspicion and anger than their confidence. It seens plausible to generalize that the more a group understands itself as oppressed, and the more it sees its legal efforts as meant to challenge that oppression, the more it will seek such assurance of solidarity from its lawyer. ${ }^{161}$

This moral or pohtical alliance between lawyer and client is a potent force. It may well give the lawyer a credibility that melds together the expertise of the professional and the intimacy of the friend. The lawyer who acquires such credibility with lier client group is in a position to influence her clients dramatically, a prospect frauglit witl potential and witl danger. The potential is that the lawyer can inspire her clients to engage im a process of political mobilization. The danger is that the lawyer can mobilize demagogically or manipulatively. If lawyers could avoid forming such close alliances, they miglit be wise to do so in order to escape this risk of demagoguery, even at the cost of sacrificing the special potential for benign influence that this solidary relationship with client groups can give them. This would be a great sacrifice, for lielping disadvantaged groups to find, and amplify, their political voice is a valuable step

160 A lawyer who has done such cases confirmed this suggestion. He commented that: when it comes to representing the Black community in matters of discrimination, it's just impossible to inuagine the lack of that sense from the chients-that sense being that there was injustice here-and I think that attorneys who don't convey that sense will have trouble, would have a lot of trouble with the comnunity.

Interview with James Liebman (Sept. 17, 1991) (transcript at 38, on file with the author).

161 I examme nore fully the functions that expressions of approval can serve inl lawyerclient relations in Ellmann, supra note 158. A number of the considerations that support the lawyer's explicit expression of agreement with her chents' values in group representation will also apply to individual representation. See id. As already discussed, however, the lawyer for a group cannot make as ready use of the empathetic community of two as can the lawyer for an individual client, see supra notes 88-101 and accompanying text. It seems likely, therefore, that the group's lawyer will lave greater call to resort to direct approval in trying to forge a bond witl her client than would a comparable lawyer for an individual client. 
indeed. ${ }^{162}$ But in any event this choice is probably not open to lawyers, regardless of whether they wish it were, for, as I have already suggested, chents are often likely to insist on entering into such an alliance with their lawyers.

Such lawyers might still try to escape the danger of inanipulating their chents by refraining from giving advice based on their own values. But this solution seems untenable as well. The lawyer who beheves in school desegregation is unlikely to be neutral in a discussion of whether to settle a desegregation case by integrating the schools or by enhancing the funding to still segregated, black schools. For her to atteinpt to give neutral counsel would not be true to herself, and so would be a denial of her own autonoiny. It might also be psychologically impossible for the lawyer, and even if she managed the feat, its falsity might be so palpable as to undercut her relationship with her chents. Indeed, chents who accept their lawyer as their ally in the perilous seas of pohitics inay well invite the lawyer to push and challenge then, as we may invite our friends and family to pressure us without necessarily seeing our autonomy as diminished; ${ }^{163}$ but as with friends and family, so with lawyers, the line between invited suggestion and unsought interference may be easily crossed.

The lawyer-ally acquires as a result a particularly challenging obligation: an obligation of constant vigilance aganist her own overreaching. The lawyer's influence is too great for her to expect coinplete success in this self-scrutiny, but that does not inean the effort is to no avail. On the contrary, there are many manipulative steps that lawyers surely can refrain from taking. The lawyer who beheved she had no obligation to respect her clients' autononiy, and sought only to press the pohitical causes in which she beheved, might advise her chent groups in speeches using all the rhetorical maneuvers of a closing

162 I will return to the lawyer's mobilizing role in Part $\mathrm{V}$ of this Article.

163 Stephen Pepper has argued that lawyers should not be granted the power to pressure their clients as the chients' spouses or friends properly could, on the ground that "[t]he lawyer, unlike the spouse or friend, is part of the formal system of law imposed by the community." Stephen L. Pepper, A Rejoinder to Professors Kaufman and Luban, 1986 Am. B. Found. Res. J. 657,665 . The lawyer who visibly shares crucial commitments with her chents, however, might be said to have acquired an informal, personal connection with them, and a concomitant right (or invitation) to bring greater pressure to bear. But we should be careful not to overstate the extent of this bond or its corollary authorization of influence. Cf. Ellmann, supra note 11, at 179-80 (arguing that disadvantaged clients and activist lawyers cannot easily achieve a "counradeship of equals"). 
arguinent to a jury. She might incite her chents towards avoidable courtrooin confrontations with the thought that provoking the judge into punitive behavior would reveal to the clients the true corruption of the legal system, or would reveal this reality to otlier inembers of the clients' community (at the clients' expense). No doubt the range of blatantly manipulative or coercive steps a Machiavellian lawyerpolitician could take is vast. All of this a lawyer who seeks both to ally witli her clients and to adhere to client-centered principles can avoid-and lopefully inore.

\section{Conclusion: Individual Autonomy AND Collective MOBILIZATION}

The guidelines for group client-centeredness in the foregoing Part are ineant in large ineasure to encourage lawyering behavior that fosters the organization, effectiveness and survival of client groups. It is quite reasonable, however, to liope for even more-to liope tliat groups of disadvantaged people miglit grow into spearheads of inucli broader community activity. Political mobilization of disadvantaged communities is a crucial goal, crucial both for the individual inen and women in those communities who find a voice through the process of shared struggle and for their communities, for which such efforts nnay win political victories that alter the broad relations between thein and the larger society. ${ }^{164}$ It is very teinpting, therefore, to ask whether lawyers can contribute to this process even inore effectively if they

164 Important as the mobilization of disadvantaged communities is, it is not the only way that political victories can be won on behalf of disadvantaged people. Lawyers niay be able to win such victories by lobbying and publicity that appeal primarily to those who wield governmental power, or to relatively privileged social groups who can influence those in government, rather than by mobilizing disadvantaged people directly. In doing such lobbying, lawyers need not even liave clients. Many class action lawsuits, similarly, may have won significant clianges benefiting the menbers of the class without significantly nobilizing the class menibers in the process. On occasion, indeed, mobilization of the class nienibers for political action may be impossible; this would be the case in the niany class actions brought on behalf of people substantially unable to speak for themselves, such as the profoundly nientally retarded. (At one time I represented the plaintiff class in sucl a case.) Class counsel may sometinies be in tacit political alliance with at lcast sone of those whon they have nained as defendants, and such alliances niay be effective. (For example, plaintiffs' lawyers in niental health cases might share with state nental health departnients a desire to extract better funding from elected officials.) But these alliances are not mobilizations of the plaintiff classes. The strategy $I$ focus on in the text is, therefore, only one of the options open to a lawyer seeking to bring political pressure to bear on behalf of disadvantaged people. 
abandon some of the constraints of client-centeredness. Much of political life, after all, is vastly more manipulative than anything that a chent-centered lawyer might undertake; politics is the domain of the rough-and-tumble, and sometimes of the demagogue.

I remain unpersuaded that allowing lawyers to borrow the norms of politics in dealing with their chents is necessary for political change. ${ }^{165}$ On the contrary, the norms of group client-centeredness appear to offer lawyers a pathway by whicli they can contribute to community mobilization while still providing substantial protection for the autonomy of the individual members of chent groups. If these guidelines have their desired effect, after all, they will foster not only groups' survival but also their growth. Althougli it must be admitted that undemocratic groups controlled by charisinatic leaders may enjoy even greater success (perhaps at a terrible price), groups that make wise decisions through democratic processes and enjoy cohesive meinberships are well positioned to spread the ideas tliey espouse in the larger communities of which they are a part. Client-centeredness alone, therefore, is potentially a boon to the political niobilization of chent communities - the very large, very loosely organized collectivities within which the chent groups we have been discussing are to be found. The lawyer's impact can be particularly great, moreover, when she joins with her chent group in ideological agreement, and then uses, hopefully with self-restraint, the new opportunities for influence that this alliance gives her.

The lawyer wielding such influence can proinote pohtical inobilization in a range of ways that do not flout, thougli they may well alter, group inembers' autonomy. In doing so, she will be helping the ineinbers to change, for political mobilization is a process of change. The kinds of change involved, however, undoubtedly vary from person to person. For soine, who are ready to act but are not experienced in doing so, the lawyer's role may simply be instructional. ${ }^{166}$ With others, who hesitate out of the self-doubt, apathy, and cynicisin that are the fruit of the very disadvantages that fraine their position in

165 See Ellmann, supra note 11, at 177-79.

166 One lawyer discussed with me how she would handle a mass meeting of discrimination victims who were potential participants in a class action. Rather than delivering a speech to the group herself-as she might once have done-she would now work closely with the people who had first become involved in the case and help them prepare to speak to the larger group. Interview with Harriet Rabb, supra note 105, at 26-31. 
society, the lawyer may seek to mstill in them - or better yet, to elicit from them-the desire to act. Perhaps she will do this by exposing them to catalyzing experiences-although slie will always need to scrutinize carefully the justifiability of immersing people in experiences whose impact they do not fully understand in advance. ${ }^{167}$ Perhaps she will encourage thein directly, by exhorting them, and there will be room for soine passion in her words to sucl group meinbersroom given to the lawyer by people who have accepted alliance with lier. But the danger of overdoing this rlietoric will always be present, and there is mucli to be said for a less flamboyant, sustained interaction between lawyer and client, in which the lawyer lielps the mein-

167 To lead unknowing clients into avoidable courtroom confrontations in order to teach them a radicalizing political lesson would, as I have already suggested, be an intolerable intrusion on chent autonouny. But not all efforts at consciousness-raising have such repellent features. Consider, for example, a well-known instance of a "catalytic" practice, im which Gary Bellow took the deposition of a farm worker housing camp's inanager at a place where the inany plaimtiffs (residents of the camp) could, and did, watch and work with Bellow in the deposition. See Coinunent, The New Public Interest Lawyers, 79 Yale L.J. 1069, 1087-88 (1970) (quoting Bellow). Seeing the camp manager forced to answer their questions was an exciting and energizing experience for the tenants, and perhaps "increased their sense of solidarity with each other and reduced their sense of vulnerability to their adversary." Simon, supra note 12, at 483 . As I now understand the events, Bellow discussed the tactic with the chients in advance, but it seems quite likely that they did not then fully grasp what impact the experience would have on them.

In an earlier article, I criticized this tactic (as I then understood it) as an intrusion on the chents' autonoiny, Ellmann, supra note 74, at 772-73, and so it may have been-although the chients' inability to predict fully what they would experience is not in itself a breach of their autonomy (people inevitably and repeatedly must make choices in such conditions of partial ignorance). But my effort im this exammation of group chent-centeredness has been to describe lawyering techniques that would protect both individual autonomy and group connection. In the process I have argned for the justifiability of modest degrees of paternalistic imtrusion by lawyers seeking to guide the functioning of their group chents. It now seems to me that some "consciousness-raising" tactics-though not all —can be justified on similar grounds, and that this particular example, even viewed as a case of paternalism, inay well be an instance of appropriate mobilizing practice.

The justifiability of such lawyer paternalism must depend on the particular circumstances. As always, lawyers should seek to minimize the extent of their interference with chent autonomy, for example by obtaining the informed consent of representative group leaders before embarking on the tactic. So, too, lawyers should prefer tactics that do not entail paternalism at all if these are available and comparably effective. Naturally, they should also look closely at the extent of the potential benefits, as well as at the severity of any potential harms. These considerations would inform a "sliding scale" analysis of the propriety of particular interventions-an analysis that should not readily license such conduct, but that might well authorize a measure of such action.

Members of the New England clinical teachers' workshop, and particularly Gary Bellow himself, helped me to think through these issues. 
bers to find together their own ways of expressing themselves, and so discover both abilities they did not know they possessed and desires they had not dared to have. ${ }^{168}$

The spectrum of lawyer roles in such change thus runs from mere instruction in skills to participation in chent self-revelation. It might be argued that as the lawyer begins to play a role that goes beyond informing her chents to transforming them, she has definitively breached the boundaries of respect for client autonomy. But transformation is part of what happens in groups, and membership in groups is a crucial part of our selfhood. We ought not to reject the possibility of sucli transformation, nor of lawyers' participation in it. Instead, we should seek to insure that the groups to which lawyers lend their support are collectivities that respect and protect, as well as change, their individual members. Groups of this sort may deserve to be called republican, or dialogic, communities. The contours of group chent-centeredness sketclied in this Article can therefore be seen as the elements of brimging such ideal communities closer to life.

168 See generally Lucie E. White, To Learn and Teach: Lessons from Driefontein on Lawyering \& Power, 1988 Wis. L. Rev. 699 (describing such a process of collective selfdiscovery and einpowerment in a South African black community, and the various ways that professionals can, and did, contribute to the community's efforts). 
